\title{
Secular sea level change in the Russian sector of the Arctic Ocean
}

\author{
A. Proshutinsky, ${ }^{1}$ I. M. Ashik, ${ }^{2}$ E. N. Dvorkin, ${ }^{2}$ S. Häkkinen, ${ }^{3}$ R. A. Krishfield, ${ }^{1}$ \\ and W. R. Peltier ${ }^{4}$ \\ Received 17 June 2003; revised 2 December 2003; accepted 30 December 2003; published 25 March 2004.
}

[1] Sea level is a natural integral indicator of climate variability. It reflects changes in practically all dynamic and thermodynamic processes of terrestrial, oceanic, atmospheric, and cryospheric origin. The use of estimates of sea level rise as an indicator of climate change therefore incurs the difficulty that the inferred sea level change is the net result of many individual effects of environmental forcing. Since some of these effects may offset others, the cause of the sea level response to climate change remains somewhat uncertain. This paper is focused on an attempt to provide first-order answers to two questions, namely, what is the rate of sea level change in the Arctic Ocean, and furthermore, what is the role of each of the individual contributing factors to observed Arctic Ocean sea level change? In seeking answers to these questions we have discovered that during the period 1954-1989 the observed sea level over the Russian sector of the Arctic Ocean is rising at a rate of approximately $0.123 \mathrm{~cm} \mathrm{yr}^{-1}$ and that after correction for the process of glacial isostatic adjustment this rate is approximately $0.185 \mathrm{~cm} \mathrm{yr}^{-1}$. There are two major causes of this rise. The first is associated with the steric effect of ocean expansion.

This effect is responsible for a contribution of approximately $0.064 \mathrm{~cm} \mathrm{yr}^{-1}$ to the total rate of rise $(35 \%)$. The second most important factor is related to the ongoing decrease of sea level atmospheric pressure over the Arctic Ocean, which contributes $0.056 \mathrm{~cm} \mathrm{yr}^{-1}$, or approximately $30 \%$ of the net positive sea level trend. A third contribution to the sea level increase involves wind action and the increase of cyclonic winds over the Arctic Ocean, which leads to sea level rise at a rate of $0.018 \mathrm{~cm} \mathrm{yr}^{-1}$ or approximately $10 \%$ of the total. The combined effect of the sea level rise due to an increase of river runoff and the sea level fall due to a negative trend in precipitation minus evaporation over the ocean is close to 0 . For the Russian sector of the Arctic Ocean it therefore appears that approximately $25 \%$ of the trend of $0.185 \mathrm{~cm} \mathrm{yr}^{-1}$, a contribution of $0.048 \mathrm{~cm} \mathrm{yr}^{-1}$, may be due to the effect of increasing Arctic Ocean mass. INDEX TERMS: 3309 Meteorology and Atmospheric Dynamics: Climatology (1620); 4207 Oceanography: General: Arctic and Antarctic oceanography; 4255 Oceanography: General: Numerical modeling; 4532 Oceanography: Physical: General circulation; 4556 Oceanography: Physical: Sea level variations; KEYWORDS: Arctic, sea level rise, decadal variability, steric effects, inverted barometer effect, glacial isostatic adjustment

Citation: Proshutinsky, A., I. M. Ashik, E. N. Dvorkin, S. Häkkinen, R. A. Krishfield, and W. R. Peltier (2004), Secular sea level change in the Russian sector of the Arctic Ocean, J. Geophys. Res., 109, C03042, doi:10.1029/2003JC002007.

\section{Introduction}

[2] Unlike most other manifestations of climate change, sea level rise is already a significant problem throughout the Arctic [Arctic Research Consortium of the united States (ARCUS), 1997; Shaw et al., 1998; Brown and Solomon, 2000; Forman and Johnson, 1998; International Arctic Science Committee (IASC), 2000; Smith and Johnson,

\footnotetext{
${ }^{1}$ Woods Hole Oceanographic Institution, Woods Hole, Massachusetts, USA.

${ }^{2}$ Arctic and Antarctic Research Institute, St. Petersburg, Russia.

${ }^{3}$ Goddard Space Flight Center, Greenbelt, Maryland, USA.

${ }^{4}$ Department of Physics, University of Toronto, Toronto, Ontario, Canada.

Copyright 2004 by the American Geophysical Union. 0148-0227/04/2003JC002007\$09.00
}

2000]. Global warming and the anticipated sea level rise in the Arctic is expected to influence shoreline erosion, sediment transport, navigation conditions, oil and gas operations, hunting, and other human activities. In January 2000 the Alaska Science and Technology Foundation sponsored a workshop entitled "The Warming World: Effects on the Alaska Infrastructure" (University of Alaska Anchorage). Workshop participants concluded that sea levels will rise, storms will be stronger and more frequent, and coastal communities now struggling with erosion will see shoreline retreat accelerate [Smith and Johnson, 2000]. The Intergovernmental Panel on Climate Change [IPCC, 2001] concluded that the rate of sea level rise in the 20th century was in the range $0.1-0.2 \mathrm{~cm} \mathrm{yr}^{-1}$ (http://www.ipcc.ch/).

[3] What, however, is the current rate of sea level rise in the Arctic Ocean and what is its cause? The search for an answer to this question constitutes a complex scientific 
problem because observed sea level change, if we are able to observe it accurately, is the net result of a myriad of individual effects of dynamic and thermodynamic processes of terrestrial, oceanic, atmospheric, and cryospheric origin.

[4] A fundamental problem in determining the rate of sea level change in the Arctic has been the lack of accurate data from sites along the Arctic Ocean coastline. With the recent (January 2003) release of the data for the Russian sector of the Arctic this circumstance has improved dramatically. Approximately 70 tide gauge stations in the Barents Sea and Siberian seas (Kara, Laptev, East Siberian, and Chukchi Seas) have recorded sea level changes from the 1950s through the 1990s (Table 1 and Figure 1). Preliminary analysis has shown that over this 50-year period, most of these stations have a positive trend in sea level [e.g., Proshutinsky et al., 2001]. These sea level data were collected by the Arctic and Antarctic Research Institute (AARI), St. Petersburg, Russia. The data sets have been made available for analysis by the international community and the monthly mean relative sea level records for all gauges are now included in the Permanent Service for Mean Sea Level archive (http://www.pol.ac.uk/psmsl/pub/nucat. dat).

[5] The existing sea level data sets in the Arctic are relatively short for the analysis of global sea level rise. Peltier and Tushingham [1989] and Douglas [1991, 1992, 1997] have stressed the importance of employing very long records for this purpose (more than 60 years). Following a detailed analysis of the sea level rise detection problem, Douglas [2001], in particularly, concluded: "What is needed for an understanding of global sea level and its relation to climate is an accurate budget of the contributors to sea level rise ...". Indeed, a major goal of the present contribution is to begin this task by calculating and assessing an accurate budget of the various contributions to sea level rise in the Arctic.

[6] The study of sea level variability in the Arctic Ocean is important in its own right, primarily, because of its practical importance for people living and working in Arctic coastal regions. For them the current rates of local sea level rise are already causing severe problems. In addition, the variability of sea level in the Arctic Ocean can be used as an indicator of changes in ocean circulation [Proshutinsky and Johnson, 1997], water, ice and sediment transport, coastal erosion, and many other processes.

[7] Major aspects of the sea level change problem, including methods of sea level change detection, as well as modeling and interpretation of sea level variability, are discussed in publications by Pugh [1987], Peltier and Tushingham [1989], Woodworth et al. [1992], Woodworth [1993], Baker [1993], Gornitz and Solow [1991], Peltier [1999], Douglas [2001], and many others. According to Pugh and Maul [1999] the height of sea level $H(t)$ is a complicated sum of numerous factors including $\mathrm{Ht}$, the height due to tides; $H b$ the height due to the air pressure effect; $H w$, the height due to winds; $H c$, the height due to ocean currents; $H s$, the height due to steric (water temperature and salinity) changes; $\mathrm{He}$, the change due to the total amount of water in the sea (precipitation, evaporation, glacier melting, river runoff related to groundwater transformations, etc.), and $\mathrm{Hg}$, geological effects such as post- glacial rebound and/or subsidence. We may then express $H(t)$ as the sum:

$$
H(t)=H t+H b+H w+H c+H s+H e+H g
$$

[8] For the Arctic, equation (1) requires modification to account for the influence of ice cover, which adds another dimension to the already complex processes influencing sea level variability. The ice cover serves to alter both the exchange of heat and momentum between the atmosphere and ocean. In addition, the growth and decay of sea ice causes both a seasonal and a multiyear adjustment to the stratification of the ocean by salinating the surface layer in winter when ice grows, and freshening the surface layer in summer when ice melts. In assessing the net influence of all these processes on sea level variability, it is essential to consider the impact of each of the various factors individually, and to combine their separate contributions to provide predictions of future conditions.

[9] Different aspects of Arctic sea level variability, extending from tidal to decadal timescales, have been investigated by different scientists for different time periods on the basis of the sea level data contained in the recently released Russian archive described above [e.g., BannovBaikov, 1974; Dvorkin et al., 1978, 2000; Proshutinsky, 1978, 1993; Proshutinsky et al., 2001; Ashik et al., 1989; Dvorkin, 1991]. Long-term variability of sea level has been investigated by Dvorkin et al. [1978, 1983, 2000] and Dvorkin [1991]. These authors employed statistical methods to estimate linear trends of each of the records and thereby estimated the rate of sea level rise for the period 1950-1985 to be in the range from -0.002 to $0.06 \mathrm{~cm} \mathrm{yr}^{-1}$, averaging about $0.04 \mathrm{~cm} \mathrm{yr}^{-1}$ for the Siberian seas. They attributed this sea level rise to vertical crust movements and inferred the occurrence of a $1.2 \mathrm{~cm}$ increase in sea level for the 15-year period 1990-2005 $\left(0.08 \mathrm{~cm} \mathrm{yr}^{-1}\right)$, but cautioned that this value could be different regionally.

[10] Pavlov and Pavlov [1999] found that in the 1980s a dramatic acceleration of the sea level rise (3-5 times more than in previous decades) had occurred. Pavlov [2000] later suggested that the major cause of this phenomenon was a change of the thermohaline circulation. In contrast, Proshutinsky et al. [2000] found that the sea level rise in the Arctic Ocean during this period could be explained by changes in atmospheric circulation (it had become more strongly cyclonic), a decrease in atmospheric sea level pressure (SLP) via the inverted barometer effect, and an increase in precipitation and river runoff. Vorobyov et al. [2000] analyzed seasonal and decadal variability in sea level in the Norwegian, Barents, Kara, Laptev, East Siberian, and Chukchi Seas and found that for the period 1946-1995 sea level rise in the Siberian seas occurred at the rate of $0.185 \mathrm{~cm} \mathrm{yr}^{-1}$ and that after corrections for the inverted barometer effect, the rate of sea level rise was found to be approximately $0.140 \mathrm{~cm} \mathrm{yr}^{-1}$. The rate of sea level change due to the ongoing process of the Glacial Isostatic Adjustment (GIA), steric and other effects were assumed by them to be negligible.

[11] On the basis of this discussion it is clear that there is disagreement among the different investigators as to the observed rates of sea level rise in the Arctic Ocean and as to the cause(s) of the phenomenon. The problem is that 
Table 1. Stations With Sea Level Data ${ }^{\mathrm{a}}$

\begin{tabular}{|c|c|c|c|c|c|}
\hline Station Number and Name & Latitude & Longitude & Period, years & Years $^{\mathrm{b}}$ & Months $^{\mathrm{c}}$ \\
\hline 1 Barentsburg ${ }^{\mathrm{d}}$ & $78.067^{\circ} \mathrm{N}$ & $14.250^{\circ} \mathrm{E}$ & $1948-1992$ & 45 & 12 \\
\hline 2 Murmansk $^{\mathrm{d}}$ & $68.967^{\circ} \mathrm{N}$ & $33.050^{\circ} \mathrm{E}$ & $1952-1992$ & 40 & 12 \\
\hline 3 Malye Karmakuly & $72.367^{\circ} \mathrm{N}$ & $52.700^{\circ} \mathrm{E}$ & $1950-1999$ & 36 & 12 \\
\hline 4 Krenkelia $^{\mathrm{d}}$ & $80.617^{\circ} \mathrm{N}$ & $58.050^{\circ} \mathrm{E}$ & $1962-1990$ & 28 & 12 \\
\hline 5 Bolvanskii Nos ${ }^{\mathrm{d}}$ & $70.450^{\circ} \mathrm{N}$ & $59.083^{\circ} \mathrm{E}$ & $1951-1992$ & 42 & 12 \\
\hline 6 Belyi Nos & $69.600^{\circ} \mathrm{N}$ & $60.217^{\circ} \mathrm{E}$ & $1957-1979$ & 23 & 12 \\
\hline 7 Ugorskii Shar $^{\mathrm{d}}$ & $69.817^{\circ} \mathrm{N}$ & $60.750^{\circ} \mathrm{E}$ & $1950-1988$ & 39 & 12 \\
\hline 8 Amderma $^{\mathrm{d}}$ & $69.750^{\circ} \mathrm{N}$ & $61.700^{\circ} \mathrm{E}$ & $1950-1999$ & 50 & 12 \\
\hline 9 Russkaia Gavan'd & $76.183^{\circ} \mathrm{N}$ & $62.583^{\circ} \mathrm{E}$ & $1953-1992$ & 40 & 12 \\
\hline 10 Ust' Kara $^{\prime}$ & $69.250^{\circ} \mathrm{N}$ & $64.517^{\circ} \mathrm{E}$ & $1950-1999$ & 44 & 12 \\
\hline 11 Harasavei & $74.417^{\circ} \mathrm{N}$ & $67.583^{\circ} \mathrm{E}$ & $1954-1993$ & 40 & 12 \\
\hline 12 Zhelania $^{\mathrm{d}}$ & $76.950^{\circ} \mathrm{N}$ & $68.550^{\circ} \mathrm{E}$ & $1951-1995$ & 45 & 12 \\
\hline 13 Popova & $73.333^{\circ} \mathrm{N}$ & $70.050^{\circ} \mathrm{E}$ & $1951-1988$ & 37 & 6 \\
\hline 14 Tadibe-Iaha $^{\mathrm{d}}$ & $70.367^{\circ} \mathrm{N}$ & $72.567^{\circ} \mathrm{E}$ & $1955-1988$ & 34 & 12 \\
\hline $15{\mathrm{Se}-\mathrm{Iaha}^{\mathrm{d}}}^{\mathrm{d}}$ & $70.150^{\circ} \mathrm{N}$ & $72.567^{\circ} \mathrm{E}$ & $1967-1991$ & 23 & 12 \\
\hline 16 Antipaiuta & $69.083^{\circ} \mathrm{N}$ & $76.850^{\circ} \mathrm{E}$ & $1965-1987$ & 23 & 12 \\
\hline 17 Vize Isl. & $79.500^{\circ} \mathrm{N}$ & $76.983^{\circ} \mathrm{E}$ & $1953-1999$ & 47 & 12 \\
\hline 18 Leskin & $72.317^{\circ} \mathrm{N}$ & $79.567^{\circ} \mathrm{E}$ & $1951-1988$ & 37 & 4 \\
\hline 19 Dikson $^{\mathrm{d}}$ & $73.500^{\circ} \mathrm{N}$ & $80.400^{\circ} \mathrm{E}$ & $1950-1996$ & 47 & 12 \\
\hline 20 Uedinenia & $77.500^{\circ} \mathrm{N}$ & $82.200^{\circ} \mathrm{E}$ & $1953-1994$ & 42 & 12 \\
\hline 21 Sopochnaia Karga & $71.867^{\circ} \mathrm{N}$ & $22.700^{\circ} \mathrm{E}$ & $1958-1997$ & 40 & 12 \\
\hline 22 Izvestii $\mathrm{CIK}^{\mathrm{d}}$ & $75.950^{\circ} \mathrm{N}$ & $82.950^{\circ} \mathrm{E}$ & $1954-1999$ & 46 & 12 \\
\hline 23 Sterlegova & $75.417^{\circ} \mathrm{N}$ & $88.900^{\circ} \mathrm{E}$ & $1950-1994$ & 45 & 12 \\
\hline 24 Isachenko & $77.150^{\circ} \mathrm{N}$ & $89.200^{\circ} \mathrm{E}$ & $1954-1992$ & 39 & 12 \\
\hline 25 Golomianyi $^{\mathrm{d}}$ & $79.550^{\circ} \mathrm{N}$ & $90.617^{\circ} \mathrm{E}$ & $1954-1999$ & 46 & 12 \\
\hline 26 Pravdy $^{\mathrm{d}}$ & $76.267^{\circ} \mathrm{N}$ & $94.767^{\circ} \mathrm{E}$ & $1950-1993$ & 44 & 12 \\
\hline 27 Russkii & $77.167^{\circ} \mathrm{N}$ & $96.433^{\circ} \mathrm{E}$ & $1951-1988$ & 38 & 12 \\
\hline 28 Krasnoflotskie $^{\mathrm{d}}$ & $78.600^{\circ} \mathrm{N}$ & $98.833^{\circ} \mathrm{E}$ & $1954-1986$ & 33 & 12 \\
\hline 29 Geiberga $^{\mathrm{d}}$ & $77.600^{\circ} \mathrm{N}$ & $101.517^{\circ} \mathrm{E}$ & $1951-1994$ & 44 & 12 \\
\hline 30 Peschanyi & $79.433^{\circ} \mathrm{N}$ & $102.483^{\circ} \mathrm{E}$ & $1962-1992$ & 31 & 12 \\
\hline 31 Solnechnaia $^{\mathrm{d}}$ & $78.200^{\circ} \mathrm{N}$ & $103.267^{\circ} \mathrm{E}$ & $1951-1988$ & 38 & 12 \\
\hline 32 Fedorova $^{\mathrm{d}}$ & $77.717^{\circ} \mathrm{N}$ & $104.300^{\circ} \mathrm{E}$ & $1950-1999$ & 45 & 12 \\
\hline 33 Andreia & $76.750^{\circ} \mathrm{N}$ & $104.433^{\circ} \mathrm{E}$ & $1951-1998$ & 48 & 12 \\
\hline 34 Malyi Taimyr & $78.083^{\circ} \mathrm{N}$ & $106.817^{\circ} \mathrm{E}$ & $1950-1990$ & 41 & 12 \\
\hline 35 Kosystyi $^{\mathrm{d}}$ & $73.650^{\circ} \mathrm{N}$ & $109.733^{\circ} \mathrm{E}$ & $1954-1988$ & 35 & 12 \\
\hline 36 Preobrazhenia $^{\mathrm{d}}$ & $74.667^{\circ} \mathrm{N}$ & $112.933^{\circ} \mathrm{E}$ & $1951-1990$ & 40 & 12 \\
\hline 37 M. Pronchishevoi & $75.533^{\circ} \mathrm{N}$ & $113.433^{\circ} \mathrm{E}$ & $1951-1969$ & 19 & 12 \\
\hline 38 Anabar & $73.217^{\circ} \mathrm{N}$ & $113.500^{\circ} \mathrm{E}$ & $1991-1999$ & 8 & 12 \\
\hline 39 Terpiai-Tumsa & $73.550^{\circ} \mathrm{N}$ & $118.667^{\circ} \mathrm{E}$ & $1956-1997$ & 42 & 12 \\
\hline 40 Ust' $^{\prime}$ Olenek & $73.000^{\circ} \mathrm{N}$ & $119.867^{\circ} \mathrm{E}$ & $1950-1997$ & 33 & 12 \\
\hline 41 Dunai & $73.933^{\circ} \mathrm{N}$ & $124.500^{\circ} \mathrm{E}$ & $1951-1999$ & 49 & 12 \\
\hline 42 Sagyllah-Ary & $73.150^{\circ} \mathrm{N}$ & $128.883^{\circ} \mathrm{E}$ & $1962-1979$ & 18 & 12 \\
\hline 43 Tiksi $^{\mathrm{d}}$ & $71.583^{\circ} \mathrm{N}$ & $128.917^{\circ} \mathrm{E}$ & $1949-1999$ & 51 & 12 \\
\hline 44 Bykov Mys & $72.000^{\circ} \mathrm{N}$ & $129.117^{\circ} \mathrm{E}$ & $1975-1997$ & 12 & 12 \\
\hline 45 Malysheva & $72.067^{\circ} \mathrm{N}$ & $129.833^{\circ} \mathrm{E}$ & $1954-1979$ & 25 & 5 \\
\hline 46 Muostakh & $71.550^{\circ} \mathrm{N}$ & $130.033^{\circ} \mathrm{E}$ & $1951-1994$ & 44 & 12 \\
\hline 47 Naiba & $70.850^{\circ} \mathrm{N}$ & $130.750^{\circ} \mathrm{E}$ & $1979-1994$ & 6 & 12 \\
\hline 48 Buor-haia & $71.950^{\circ} \mathrm{N}$ & $132.767^{\circ} \mathrm{E}$ & $1954-1992$ & 22 & 12 \\
\hline 49 Uadei & $71.517^{\circ} \mathrm{N}$ & $136.417^{\circ} \mathrm{E}$ & $1953-1993$ & 32 & 12 \\
\hline 50 Kotel'nyi & $76.000^{\circ} \mathrm{N}$ & $137.867^{\circ} \mathrm{E}$ & $1951-1999$ & 49 & 12 \\
\hline 51 Sannikova $^{\mathrm{d}}$ & $74.667^{\circ} \mathrm{N}$ & $138.900^{\circ} \mathrm{E}$ & $1950-1999$ & 50 & 12 \\
\hline 52 Kigiliakh & $73.333^{\circ} \mathrm{N}$ & $139.867^{\circ} \mathrm{E}$ & $1951-1999$ & 49 & 12 \\
\hline 53 Sviatoi Nos ${ }^{\mathrm{d}}$ & $72.833^{\circ} \mathrm{N}$ & $140.733^{\circ} \mathrm{E}$ & $1951-1986$ & 36 & 12 \\
\hline 54 Zemlia Bunge & $74.833^{\circ} \mathrm{N}$ & $142.117^{\circ} \mathrm{E}$ & $1951-1986$ & 36 & 12 \\
\hline 55 Shalaurova & $73.183^{\circ} \mathrm{N}$ & $143.233^{\circ} \mathrm{E}$ & $1950-1999$ & 49 & 12 \\
\hline 56 Nemkova & $71.417^{\circ} \mathrm{N}$ & $150.750^{\circ} \mathrm{E}$ & $1956-1979$ & 21 & 7 \\
\hline 57 Zhokhova & $76.150^{\circ} \mathrm{N}$ & $152.833^{\circ} \mathrm{E}$ & $1959-1992$ & 33 & 12 \\
\hline 58 Ambarchik $^{\mathrm{d}}$ & $69.617^{\circ} \mathrm{N}$ & $162.300^{\circ} \mathrm{E}$ & $1950-1999$ & 50 & 12 \\
\hline 59 Chetyrehstolbovoi & $70.633^{\circ} \mathrm{N}$ & $162.483^{\circ} \mathrm{E}$ & $1951-1993$ & 43 & 12 \\
\hline 60 Rau-Chua & $69.500^{\circ} \mathrm{N}$ & $166.583^{\circ} \mathrm{E}$ & $1950-1999$ & 46 & 12 \\
\hline 61 Aion & $69.933^{\circ} \mathrm{N}$ & $167.983^{\circ} \mathrm{E}$ & $1954-1999$ & 46 & 12 \\
\hline 62 Pevek $^{\mathrm{d}}$ & $69.700^{\circ} \mathrm{N}$ & $170.250^{\circ} \mathrm{E}$ & $1950-1999$ & 50 & 12 \\
\hline 63 Valkarkai & $70.083^{\circ} \mathrm{N}$ & $170.933^{\circ} \mathrm{E}$ & $1956-1992$ & 37 & 12 \\
\hline 64 Billingsa & $69.883^{\circ} \mathrm{N}$ & $175.767^{\circ} \mathrm{E}$ & $1953-1994$ & 42 & 12 \\
\hline 65 Mys Shmidta $^{\mathrm{d}}$ & $68.900^{\circ} \mathrm{N}$ & $179.367^{\circ} \mathrm{W}$ & $1950-1993$ & 44 & 12 \\
\hline 66 Vrangelia $^{\mathrm{d}}$ & $70.983^{\circ} \mathrm{N}$ & $178.483^{\circ} \mathrm{W}$ & $1950-1999$ & 50 & 12 \\
\hline 67 Vankarem & $67.833^{\circ} \mathrm{N}$ & $175.833^{\circ} \mathrm{W}$ & $1950-1999$ & 50 & 12 \\
\hline 68 Koluchin & $67.483^{\circ} \mathrm{N}$ & $174.650^{\circ} \mathrm{W}$ & $1950-1990$ & 41 & 12 \\
\hline 69 Providenia $^{\mathrm{d}}$ & $64.417^{\circ} \mathrm{N}$ & $173.233^{\circ} \mathrm{W}$ & $1951-1982$ & 32 & 12 \\
\hline 70 Netten & $66.967^{\circ} \mathrm{N}$ & $171.933^{\circ} \mathrm{W}$ & $1950-1994$ & 45 & 12 \\
\hline 71 Ratmanova $^{\mathrm{d}}$ & $66.850^{\circ} \mathrm{N}$ & $169.133^{\circ} \mathrm{E}$ & $1950-1991$ & 40 & 12 \\
\hline
\end{tabular}




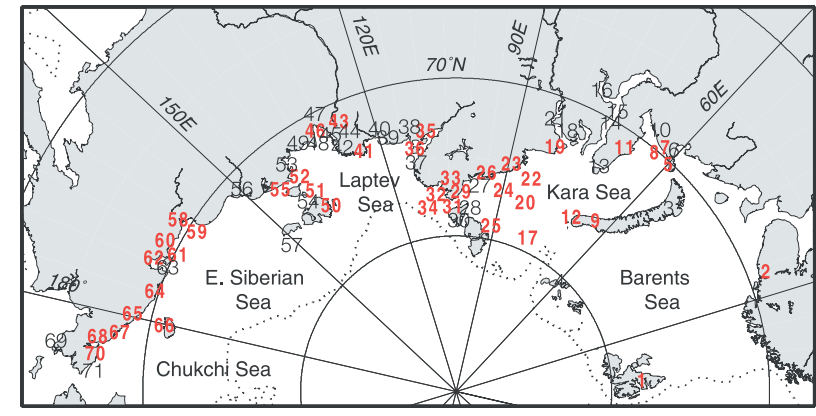

Figure 1. Locations of tide gauges in the Arctic seas. Numbers correspond to the stations shown in Table 1. Red denotes stations with complete data sets.

different scientists employ different data sets and focus upon different time periods for data averaging, statistical analysis and modeling.

[12] The primary goal of this publication is to estimate the secular rate of sea level change in the Arctic Ocean and to evaluate the relative roles of the different factors that influence this change. Sea level records are influenced by a variety of processes in addition to those that contribute to the secular trend. Therefore we desire to employ the largest possible number of stations in order to be able to exclude the influence of local conditions and thereby improve signal-to-noise ratio for larger regions. Numerical modeling methods are also critical in this study to estimate the roles of the different factors that contribute to sea level variability. In this approach, we employ known forcing effects, namely those due to wind, water density, river runoff, precipitation, evaporation, etc., to compute the model sea level signals and then calculate the trends of sea level change induced by these various factors. This procedure also allows us to remove the influence of the major known processes from the sea level records. The residual sea level variability is attributed to the factors which were not taken into account in the regional models (for example, water mass exchange with the rest of the globe through our model boundaries) and to model errors and errors in the external forcing.

\section{Data Description}

[13] Instrumental measurements of sea level in the Arctic seas began in the 1920s and 1930s. Stationary sea level observations were first begun in the Kara Sea (Dickson Island) in 1933, in the Laptev Sea (Tiksi Bay) in 1934, in the Chukchi Sea (Cape Schmidt) in 1935, and in the East Siberian Sea (Ambarchik Bay) in 1939. There were 71 stations involved in the sea level observational program in the mid-1980s. As a result of economic problems in Russia, many stations were closed in the $1990 \mathrm{~s}$, and at present there are only 21 stations operating in the Siberian seas.

[14] The observations based upon manual readings have been carried out four times a day with an accuracy of $1 \mathrm{~cm}$.
Automated tide gauge stations equipped with tide gauge recorders (see Table 1 for their locations) have a sampling frequency of 1 hour and an accuracy of $1 \mathrm{~cm}$. Monthly data quality control includes both visual data control and statistical control. Observations at some stations have had different locations in summer and winter, some of which were interrupted during replacement. Therefore much of the sea level data collected before 1949-1950 cannot be used because of the absence of a reliable geodetic survey. All stations shown in Table 1 have one or more geodetic benchmark installed on stable ground. Periodic (usually annually, but for some stations every summer month because of instability related to permafrost) geodetic surveys have been made to each gauge to determine if any vertical changes in the gauge mount have occurred. If a change in the sea level gauge mount occurred, an adjustment was made. The sea level data used in this paper are relative to benchmarks in solid rock.

[15] The monthly sea level data are calculated using daily sea level data. The monthly data based on four measurements per day are very close to the calculated monthly data based on observations made at 1 -hour intervals. It is estimated that the error does not exceed $2 \mathrm{~cm}$ more than $0.3 \%$ of the time. The annual sea level based on 6 -hour interval observations coincides with results based on 1-hour observing intervals.

[16] Monthly mean relative sea levels were provided by the Arctic and Antarctic Research Institute for 71 stations (Figure 1 and Table 1) located in the Barents and Siberian Seas. The time series of sea level variability generally cover the period between 1948 and 2000 but temporal coverage differs significantly from station to station. Table 1 shows the names and coordinates of all available stations. In addition to the names and locations, start and end years, number of years with observations, and typical number of months of the year with observations from each time series are indicated. Gaps in the observations exist where the number of years is less than the difference between the start and end years, and only partial year records exist where the number of months is less than 12 .

[17] Figures 2-4 are composites of sea level variability in the Siberian seas and show all data for three types of stations: stations located in the vicinity of river mouths, island stations, and coastal stations that are far away from rivers. In general, this subdivision of stations based on their location results from the character of seasonal sea level variability. Coastal stations located in river deltas have a well pronounced peak in June-July associated with increased river runoff due to snow melting. The range of sea level variability at these stations is higher than at the other coastal and island stations. In turn, island stations display the smallest variability during the seasonal cycle because their sea levels are less responsive to storm surges because of their location in the open sea.

[18] The statistical characteristics of the observed sea level variability are shown in Table 2 and Table 3 for only

\footnotetext{
Notes to Table 1

${ }^{\mathrm{a}} \mathrm{See}$ also Figure 1.

${ }^{\mathrm{b}}$ Number of years with obervations.

${ }^{\mathrm{c}}$ Typical number of months of observations per year (months).

${ }^{\mathrm{d}}$ Automated tide gauge stations equipped with tide-gauge recorders.
} 

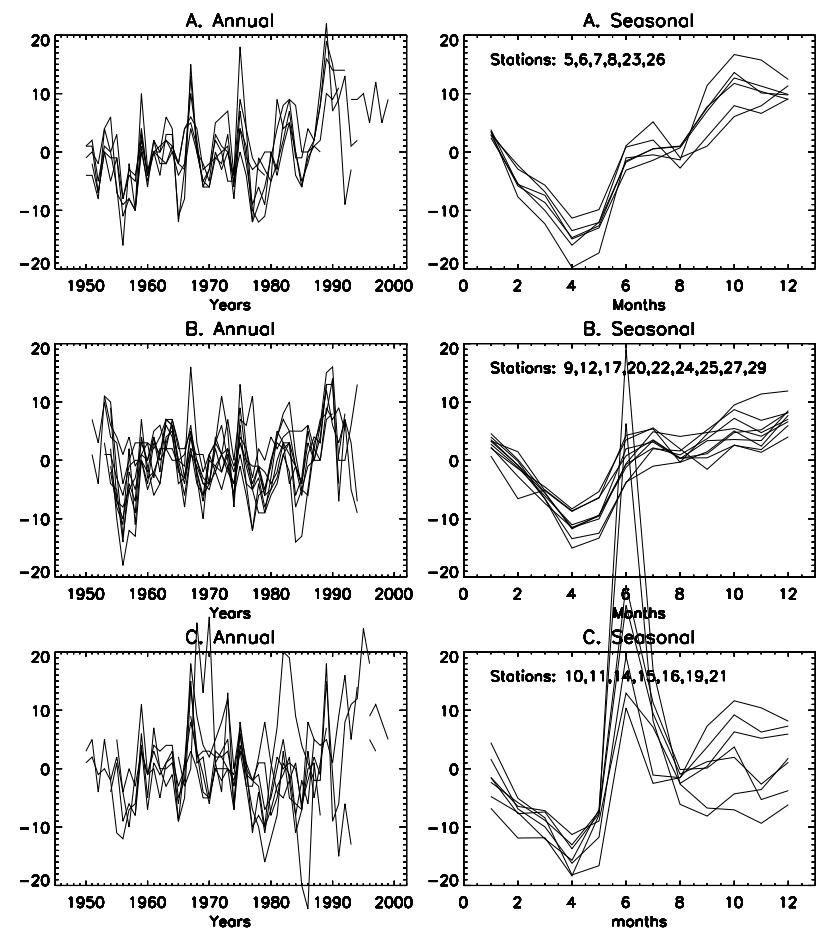

Figure 2. Kara Sea time series of (left) annual and (right) seasonal sea level $(\mathrm{cm})$ at (a) coastal stations without influence of river runoff, (b) at island stations, and (c) at stations influenced by river runoff. Station numbers for each region are shown in right panels.
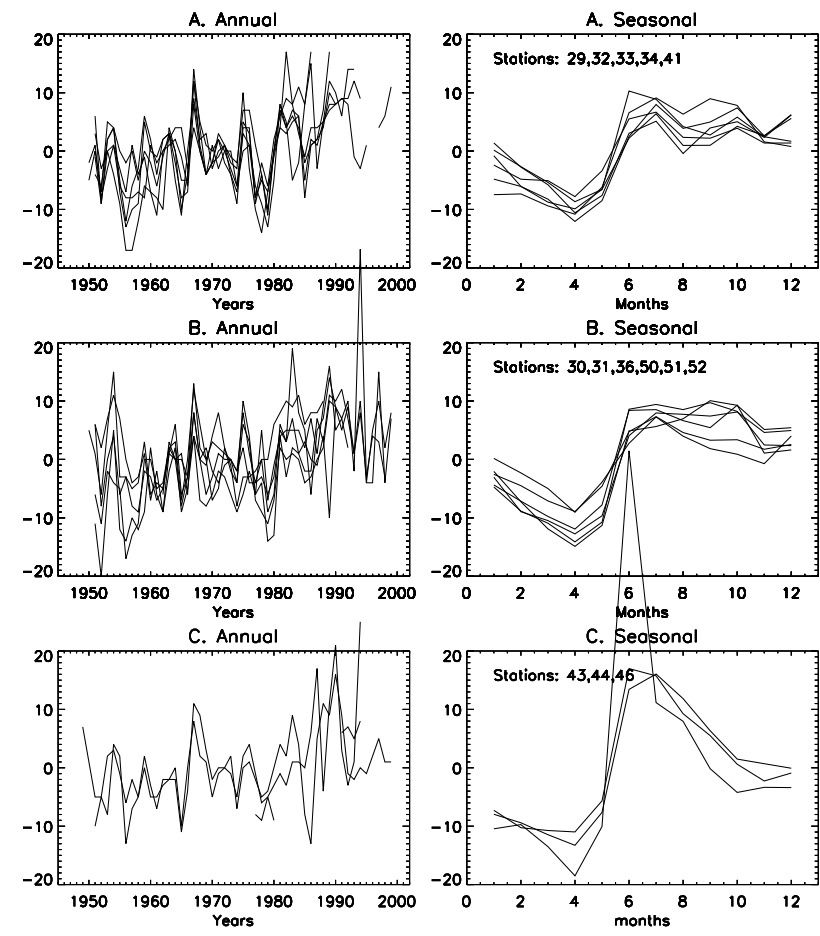

Figure 3. Laptev Sea time series of (left) annual and (right) seasonal sea level (cm) at (a) coastal stations without influence of river runoff, (b) at island stations, and (c) at stations influenced by river runoff. Station numbers for each region are shown in right panels.
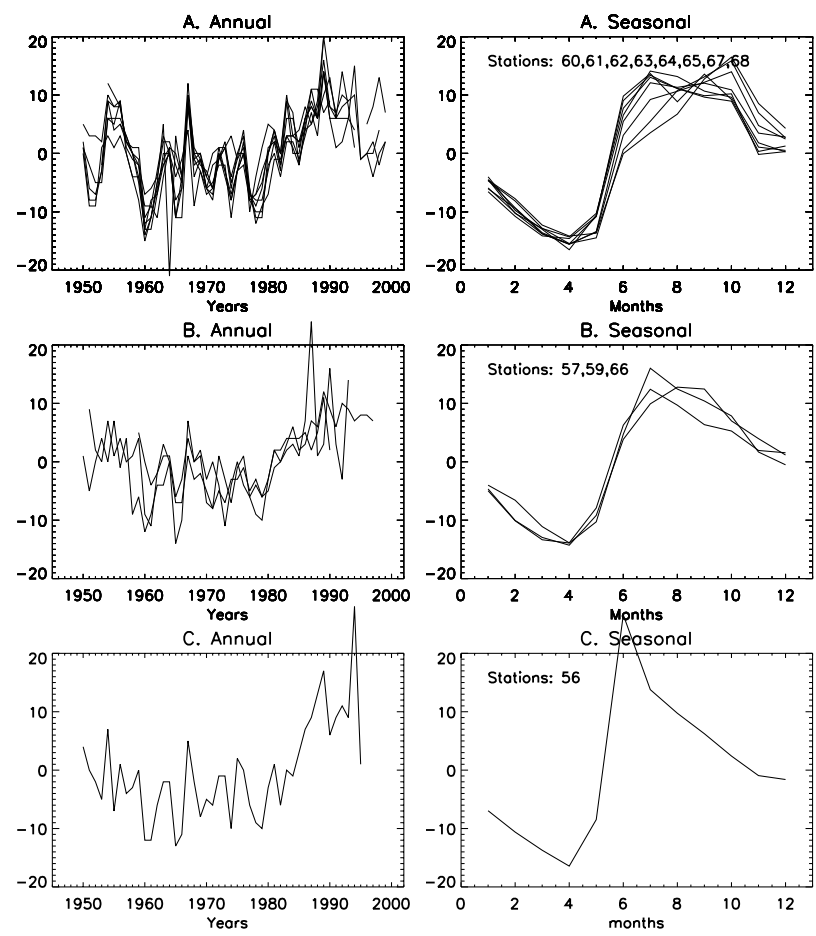

Figure 4. East Siberian and Chukchi Seas time series of (left) annual and (right) seasonal sea level (cm) at (a) coastal stations without influence of river runoff, (b) at island stations, and (c) at stations influenced by river runoff. Station numbers for each region are shown in right panels.

40 time series, namely those which span the longest time interval and have the most complete observations. In this paper, these data will be employed to statistically decompose the sea level measurements into spatial and temporal components between 1954 and 1989. In order to be included in the list of these stations, the sea level time series must have no more than 10 missing points (months) out of 420 possible between the 1954 and 1989 start and end dates. In fact, only one of these time series (station 1, Barentsburg) contained more than 1 missing point, while two other stations (6 and 33) contained a single missing month. In the station 1 time series, a 3 month data gap exists in both 1978 and 1984, and a 1-month gap in 1987.

\section{Secular Sea Level Trends From Observations}

[19] In Table 2, the statistical characteristics of each time series are presented for the 40 stations mentioned above, for all years of available data. Gaps in each station time series are linearly interpolated and the trend determined by least squares linear regression of the time series covering the entire period of observation. The average duration of observations of sea level at the Arctic coastal stations is 538 months or 44.8 years. Mean standard deviation of sea level is $14.331 \mathrm{~cm}$ and the trend is $0.177 \pm 0.047 \mathrm{~cm} \mathrm{yr}^{-1}$. These statistical parameters have been calculated for the entire period of observation and change significantly from station to station and from region to region (Table 2 and Figure 5). For instance, the trend of sea level change from observational data varies from $-0.048 \pm 0.045 \mathrm{~cm} \mathrm{yr}^{-1}$ in 
Table 2. Variability and Trends From Observed and GIA-Corrected Data ${ }^{a}$

\begin{tabular}{|c|c|c|c|c|c|c|c|c|c|c|}
\hline & \multirow[b]{2}{*}{$\mathrm{D},{ }^{\mathrm{b}}$ Months } & \multicolumn{3}{|c|}{ Observations $^{\mathrm{c}}$} & \multicolumn{3}{|c|}{ GIA-1 ${ }^{\mathrm{d}}$} & \multicolumn{3}{|c|}{ GIA-2 ${ }^{\mathrm{e}}$} \\
\hline & & $\mathrm{STD}^{\mathrm{f}}$ & $\mathrm{TRD}^{\mathrm{g}}$ & $\mathrm{ERR}^{\mathrm{h}}$ & $\operatorname{STD}^{f}$ & $\mathrm{TRD}^{\mathrm{g}}$ & $\mathrm{ERR}^{\mathrm{h}}$ & $\mathrm{STD}^{\mathrm{f}}$ & $\mathrm{TRD}^{\mathrm{g}}$ & $\mathrm{ERR}^{\mathrm{h}}$ \\
\hline Barentsburg & 540 & 10.143 & -0.151 & 0.033 & -0.039 & 10.057 & -0.112 & -0.085 & 9.988 & -0.066 \\
\hline Murmansk & 492 & 11.980 & 0.074 & 0.046 & -0.229 & 12.475 & 0.303 & -0.270 & 12.624 & 0.344 \\
\hline Russkaia Gavan' & 474 & 12.483 & -0.066 & 0.050 & -0.336 & 12.836 & 0.270 & -0.206 & 12.562 & 0.140 \\
\hline Barents Sea & 502 & 11.535 & -0.048 & 0.043 & -0.201 & 11.789 & 0.154 & -0.187 & 11.725 & 0.139 \\
\hline Zhelania & 529 & 11.748 & -0.050 & 0.040 & -0.284 & 12.103 & 0.234 & 0.165 & 11.822 & 0.115 \\
\hline Bolvanskii Nos & 514 & 13.922 & 0.292 & 0.048 & -0.224 & 14.884 & 0.516 & -0.056 & 14.118 & 0.348 \\
\hline Ugorskii Shar & 480 & 12.720 & 0.073 & 0.050 & -0.186 & 13.040 & 0.259 & -0.040 & 12.759 & 0.113 \\
\hline Amderma & 600 & 13.710 & 0.259 & 0.037 & -0.179 & 14.628 & 0.438 & -0.037 & 13.865 & 0.296 \\
\hline Harasavei & 480 & 17.043 & 0.095 & 0.067 & -0.208 & 17.364 & 0.303 & -0.024 & 17.063 & 0.119 \\
\hline Vize Isl & 480 & 11.002 & 0.081 & 0.043 & -0.155 & 11.295 & 0.236 & -0.167 & 11.330 & 0.248 \\
\hline Dikson & 559 & 16.041 & 0.197 & 0.050 & -0.171 & 16.578 & 0.368 & -0.015 & 16.076 & 0.212 \\
\hline Uedinenia & 502 & 11.922 & 0.078 & 0.044 & -0.217 & 12.407 & 0.295 & -0.127 & 12.140 & 0.205 \\
\hline Izvestii CIK & 534 & 12.931 & 0.061 & 0.044 & -0.214 & 13.382 & 0.275 & -0.074 & 13.023 & 0.135 \\
\hline Sterlegova & 545 & 15.988 & 0.228 & 0.051 & -0.159 & 16.505 & 0.387 & -0.069 & 16.181 & 0.297 \\
\hline Isachenko & 471 & 12.466 & 0.356 & 0.048 & -0.187 & 13.306 & 0.543 & -0.117 & 12.957 & 0.473 \\
\hline Golomianyi & 526 & 10.338 & 0.099 & 0.035 & -0.115 & 10.613 & 0.214 & -0.125 & 10.646 & 0.224 \\
\hline Pravdy & 537 & 15.552 & 0.272 & 0.051 & -0.143 & 16.071 & 0.415 & -0.093 & 15.867 & 0.365 \\
\hline Geiberga & 524 & 11.576 & 0.274 & 0.038 & -0.097 & 11.999 & 0.371 & -0.089 & 11.960 & 0.363 \\
\hline Solnechnaia & 468 & 11.712 & 0.470 & 0.043 & -0.075 & 12.117 & 0.545 & -0.078 & 12.134 & 0.548 \\
\hline Fedorova & 493 & 12.600 & 0.203 & 0.047 & -0.075 & 12.801 & 0.278 & -0.073 & 12.794 & 0.276 \\
\hline Kara Sea & 515 & 13.204 & 0.187 & 0.046 & -0.168 & 13.693 & 0.355 & -0.084 & 13.421 & 0.271 \\
\hline Andreia & 544 & 13.743 & 0.379 & 0.042 & -0.082 & 14.166 & 0.461 & -0.069 & 14.095 & 0.448 \\
\hline Malyi Taimyr & 504 & 9.848 & 0.273 & 0.034 & -0.050 & 10.069 & 0.323 & -0.058 & 10.107 & 0.331 \\
\hline Preobrazhenia & 492 & 13.162 & 0.136 & 0.050 & -0.044 & 13.236 & 0.180 & -0.037 & 13.223 & 0.173 \\
\hline Dunai & 595 & 15.744 & 0.175 & 0.045 & -0.013 & 15.775 & 0.188 & -0.032 & 15.823 & 0.207 \\
\hline Tiksi & 624 & 14.895 & 0.123 & 0.039 & -0.033 & 14.964 & 0.156 & -0.051 & 15.009 & 0.174 \\
\hline Muostakh & 538 & 17.475 & 0.300 & 0.057 & -0.034 & 17.578 & 0.334 & -0.052 & 17.637 & 0.352 \\
\hline Kotel'nyi & 597 & 17.205 & 0.440 & 0.046 & 0.001 & 17.200 & 0.439 & -0.019 & 17.307 & 0.459 \\
\hline Sannikova & 612 & 15.592 & 0.094 & 0.043 & -0.012 & 15.609 & 0.106 & -0.030 & 15.638 & 0.124 \\
\hline Kigiliakh & 598 & 13.985 & 0.025 & 0.040 & -0.029 & 14.002 & 0.054 & -0.042 & 14.014 & 0.067 \\
\hline Laptev Sea & 567 & 14.628 & 0.216 & 0.044 & -0.033 & 14.733 & 0.249 & -0.043 & 14.761 & 0.259 \\
\hline Shalaurova & 591 & 14.248 & 0.055 & 0.041 & -0.029 & 14.277 & 0.084 & -0.045 & 14.297 & 0.100 \\
\hline Ambarchik & 572 & 18.624 & 0.364 & 0.055 & -0.032 & 18.747 & 0.396 & -0.041 & 18.784 & 0.405 \\
\hline Chetyhrehstolbovoi & 519 & 17.011 & 0.134 & 0.060 & -0.021 & 17.039 & 0.155 & -0.030 & 17.052 & 0.164 \\
\hline Rau-Chua & 550 & 16.563 & 0.001 & 0.053 & -0.028 & 16.568 & 0.029 & -0.035 & 16.570 & 0.036 \\
\hline Aion & 561 & 16.159 & 0.073 & 0.051 & -0.021 & 16.179 & 0.094 & -0.027 & 16.185 & 0.100 \\
\hline Pevek & 592 & 16.196 & 0.211 & 0.046 & -0.021 & 16.255 & 0.232 & -0.026 & 16.269 & 0.237 \\
\hline Billingsa & 511 & 16.614 & 0.186 & 0.059 & -0.009 & 16.629 & 0.195 & -0.011 & 16.633 & 0.197 \\
\hline East Sib. Sea & 557 & 16.488 & 0.146 & 0.052 & -0.023 & 16.528 & 0.169 & -0.031 & 16.541 & 0.177 \\
\hline Mys Shmidta & 532 & 15.788 & 0.180 & 0.053 & -0.008 & 15.803 & 0.188 & -0.005 & 15.798 & 0.185 \\
\hline Vrangelia & 604 & 13.546 & 0.274 & 0.036 & 0.021 & 13.460 & 0.253 & 0.026 & 13.440 & 0.248 \\
\hline Vankarem & 600 & 16.847 & 0.323 & 0.046 & -0.006 & 16.871 & 0.329 & 0.000 & 16.847 & 0.323 \\
\hline Koluchin & 504 & 16.526 & 0.278 & 0.059 & -0.003 & 16.534 & 0.281 & 0.005 & 16.514 & 0.273 \\
\hline Netten & 537 & 17.604 & 0.204 & 0.058 & 0.000 & 17.604 & 0.204 & 0.010 & 17.585 & 0.194 \\
\hline Chukchi Sea & 555 & 16.062 & 0.252 & 0.050 & 0.001 & 16.054 & 0.251 & 0.007 & 16.037 & 0.245 \\
\hline Mean & 538 & 14.3331 & 0.177 & 0.047 & -0.094 & 14.576 & 0.270 & -0.062 & 14.468 & 0.239 \\
\hline
\end{tabular}

${ }^{\mathrm{a}}$ Bold indicates region averages.

${ }^{\mathrm{b}}$ Duration of observations (months).

${ }^{\mathrm{c}}$ Trend and statistics from observations.

${ }^{\mathrm{d}}$ GIA trends from model ICE-4G.

${ }^{\mathrm{e}} \mathrm{GIA}$ trends from model ICE-5G.

${ }^{\mathrm{f}}$ Standard deviation $(\mathrm{cm})$.

${ }^{\mathrm{g}}$ Trend $\left(\mathrm{cm} \mathrm{yr}^{-1}\right)$.

${ }^{\mathrm{h}}$ Standard error of trend $\left(\mathrm{cm} \mathrm{yr}^{-1}\right)$.

the Barents Sea, $0.187 \pm 0.046 \mathrm{~cm} \mathrm{yr}^{-1}$ in the Kara Sea, $0.216 \pm 0.044 \mathrm{~cm} \mathrm{yr}^{-1}$ in the Laptev Sea, $0.146 \pm$ $0.052 \mathrm{~cm} \mathrm{yr}^{-1}$ in the East Siberian Sea, and $0.252 \pm$ $0.050 \mathrm{~cm} \mathrm{yr}^{-1}$ in the Chukchi Sea. To some degree, these differences in the trend could be explained by the fact that these characteristics were obtained for different periods of observation. In order to correct this problem we calculated statistical parameters for the common period of observations 1954-1989 (Table 3). One sees that the mean trend of $0.123 \pm 0.057 \mathrm{~cm} \mathrm{yr}^{-1}$ for this period is smaller than it was for the entire period of observations $(0.177 \pm 0.047 \mathrm{~cm}$, Table 2$)$ and that the general disagreement in the observed trends among coastal seas is not improved. Therefore there are other factors, which possibly affect the secular sea level trend in each of these seas and one of these is associated with the process of glacial isostatic adjustment (GIA). This factor is discussed in the next section.

\section{Glacial Isostatic Adjustment}

[20] The ongoing Glacial Isostatic Adjustment (GIA) process due to the deglaciation of the northern hemisphere continents commenced approximately 21,000 year ago and ended approximately 4,000 years ago. The process continues to exert a highly significant influence on modern tide 
Table 3. Observed and Simulated Trends $1954-1989^{\mathrm{a}}$

\begin{tabular}{|c|c|c|c|c|c|c|c|c|c|c|}
\hline & Observations & GIA & $\mathrm{COR}$ & Wind & Inv. & P-E & River & Steric & Full & Res. \\
\hline Barentsburg & -0.156 & -0.085 & -0.071 & 0.015 & 0.100 & -0.001 & 0.000 & -0.016 & 0.098 & -0.169 \\
\hline Murmansk & -0.091 & -0.270 & 0.179 & 0.010 & 0.095 & -0.001 & 0.001 & -0.002 & 0.103 & 0.076 \\
\hline Russkaia Gavan' & -0.113 & -0.206 & 0.093 & 0.012 & 0.075 & -0.001 & 0.000 & 0.004 & 0.090 & 0.003 \\
\hline Barents Sea & -0.120 & -0.187 & 0.067 & 0.012 & 0.090 & -0.001 & 0.000 & 0.008 & 0.097 & -0.030 \\
\hline Zhelania & -0.255 & -0.165 & -0.090 & 0.012 & 0.081 & -0.002 & 0.000 & -0.008 & 0.083 & -0.173 \\
\hline Bolvanskii Nos & 0. & -0.056 & 0.189 & 0.002 & 0.068 & -0.002 & 0.000 & 0.000 & 0.068 & 0.121 \\
\hline Ugorskii Shar & 0.057 & -0.040 & 0.097 & 0.011 & 0.092 & -0.003 & 0.000 & -0.008 & 0.092 & 0.005 \\
\hline Amderma & 0.110 & -0.037 & 0.147 & 0.011 & 0.092 & -0.003 & 0.000 & 0.000 & 0.100 & 0.047 \\
\hline Harasavei & 0.252 & -0.024 & 0.276 & 0.003 & 0.054 & -0.002 & 0.000 & 0.012 & 0.067 & 0.209 \\
\hline Vise Isl & 0.031 & -0.167 & 0.198 & 0.009 & 0.086 & -0.002 & 0.000 & 0.011 & 0.104 & 0.094 \\
\hline Dikson & 0.090 & -0.015 & 0.105 & 0.036 & 0.065 & -0.002 & 0.006 & 0.097 & 0.202 & -0.097 \\
\hline Uedinenia & 0.146 & -0.127 & 0.273 & 0.019 & 0.077 & -0.001 & 0.000 & -0.006 & 0.089 & 0.184 \\
\hline Izvestia CIK & 0.049 & -0.074 & 0.123 & 0.036 & 0.071 & -0.002 & 0.002 & 0.035 & 0.142 & -0.019 \\
\hline Sterlegova & 0.173 & -0.069 & 0.242 & 0.044 & 0.070 & -0.003 & 0.005 & 0.054 & 0.170 & 0.072 \\
\hline Isachenko & 0.312 & -0.117 & 0.429 & 0.026 & 0.076 & -0.001 & 0.001 & 0.022 & 0.124 & 0.305 \\
\hline Golomianyi & 0.023 & -0.125 & 0.148 & 0.017 & 0.079 & -0.003 & 0.001 & 0.022 & 0.116 & 0.032 \\
\hline Pravdy & 0.221 & -0.093 & 0.314 & 0.043 & 0.073 & -0.002 & 0.003 & 0.045 & 0.162 & 0.152 \\
\hline Geiberga & 0.170 & -0.089 & 0.259 & 0.035 & 0.074 & -0.002 & 0.002 & 0.059 & 0.168 & 0.091 \\
\hline Solnechnaia & 0.498 & -0.078 & 0.576 & 0.014 & 0.072 & -0.001 & 0.001 & 0.060 & 0.146 & 0.430 \\
\hline Fedorova & 0.128 & -0.073 & 0.201 & 0.023 & 0.073 & -0.001 & 0.000 & 0.055 & 0.150 & 0.051 \\
\hline Kara Sea & 0.134 & -0.084 & 0.218 & 0.021 & 0.075 & -0.002 & 0.001 & 0.049 & 0.124 & 0.094 \\
\hline Andreia & 0.403 & -0.069 & 0.472 & 0.013 & 0.070 & -0.001 & 0.001 & 0.074 & 0.157 & 0.315 \\
\hline Malyi Taimyr & 0.238 & -0.058 & 0.296 & 0.007 & 0.071 & -0.003 & 0.000 & 0.042 & 0.117 & 0.179 \\
\hline Preobrazhenia & 0.130 & -0.037 & 0.167 & 0.009 & 0.064 & -0.002 & 0.001 & 0.101 & 0.173 & -0.006 \\
\hline Dunai & 0.180 & -0.032 & 0.212 & -0.042 & 0.051 & -0.002 & 0.003 & 0.144 & 0.154 & 0.059 \\
\hline Tiksi & 0.131 & -0.051 & 0.182 & -0.080 & 0.054 & -0.002 & 0.002 & 0.144 & 0.118 & 0.064 \\
\hline Muostakh & 0.176 & -0.052 & 0.228 & -0.104 & 0.054 & -0.002 & 0.002 & 0.177 & 0.127 & 0.101 \\
\hline Kotel'nyi & 0.417 & -0.019 & 0.436 & 0.045 & 0.023 & -0.002 & 0.003 & 0.127 & 0.196 & 0.240 \\
\hline Sannikova & 0.052 & -0.030 & 0.082 & -0.044 & 0.015 & -0.002 & 0.002 & 0.198 & 0.169 & -0.087 \\
\hline Kigiliakh & -0.073 & -0.042 & -0.031 & -0.090 & 0.017 & -0.002 & 0.003 & 0.228 & 0.156 & -0.187 \\
\hline Laptev Sea & 0.184 & -0.043 & 0.227 & -0.032 & 0.047 & -0.002 & 0.002 & 0.137 & 0.152 & 0.075 \\
\hline Shalaurova & 0.026 & -0.045 & 0.071 & -0.041 & 0.009 & -0.003 & 0.002 & 0.151 & 0.118 & -0.047 \\
\hline Ambarchik & 0.229 & -0.041 & 0.270 & 0.037 & 0.017 & -0.003 & 0.003 & 0.130 & 0.184 & 0.086 \\
\hline Chetyrehstolbovoi & 0.137 & -0.030 & 0.167 & 0.049 & 0.010 & -0.002 & 0.002 & 0.121 & 0.180 & -0.013 \\
\hline Rau-Chua & 0.015 & -0.035 & 0.050 & 0.049 & 0.019 & -0.002 & 0.002 & 0.104 & 0.172 & -0.122 \\
\hline Aion & -0.087 & -0.027 & -0.060 & 0.059 & 0.019 & -0.002 & 0.002 & 0.086 & 0.164 & -0.224 \\
\hline Pevek & 0.152 & -0.026 & 0.178 & 0.081 & 0.021 & -0.003 & 0.001 & 0.053 & 0.153 & 0.025 \\
\hline Billingsa & 0.077 & -0.011 & 0.088 & 0.068 & 0.023 & -0.002 & 0.001 & 0.056 & 0.146 & -0.058 \\
\hline East Sib. Sea & 0.078 & -0.031 & 0.109 & 0.043 & 0.017 & -0.003 & 0.002 & 0.100 & 0.159 & -0.050 \\
\hline Mys Shmidta & 0.082 & -0.005 & 0.087 & 0.066 & 0.038 & -0.002 & 0.001 & 0.038 & 0.141 & -0.054 \\
\hline Vrangelia & 0.195 & 0.026 & 0.169 & 0.072 & 0.031 & -0.003 & 0.000 & 0.077 & 0.177 & -0.008 \\
\hline Vankarem & 0.256 & 0.000 & 0.256 & 0.069 & 0.047 & -0.001 & 0.002 & 0.024 & 0.141 & 0.115 \\
\hline Koluchin & 0.214 & 0.005 & 0.209 & 0.055 & 0.052 & -0.001 & 0.002 & 0.027 & 0.135 & 0.074 \\
\hline Netten & 0.201 & 0.010 & 0.191 & 0.057 & 0.053 & -0.001 & 0.001 & 0.024 & 0.134 & 0.057 \\
\hline Chukchi Sea & 0.190 & 0.007 & 0.182 & 0.064 & 0.044 & -0.001 & 0.001 & 0.038 & 0.146 & 0.036 \\
\hline Mean & 0.123 & -0.062 & 0.185 & 0.018 & 0.056 & -0.002 & 0.001 & 0.064 & 0.137 & 0.048 \\
\hline
\end{tabular}

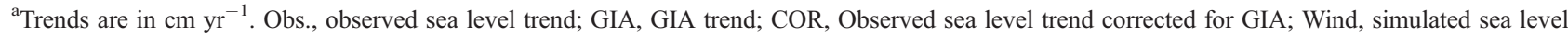
trend associated with wind-forcing only; Inv., simulated sea level trend due to inverted barometer effect; P-E, simulated sea level trend due to P-E effect; Steric, simulated sea level trend due to steric effects; Full, all forcing effects without GIA; and Res., residual trend. Bold indicates region averages.

gauge measurements of secular sea level trends [e.g., Peltier, 1986; Peltier and Tushingham, 1989, 1991]. The reason why this process continues to exert its influence so many thousands of years after deglaciation was complete is a consequence of the relatively high value of mantle viscosity, the Earth property that determines the rate at which isostatic equilibrium is restored following the emplacement or removal of a surface mass load. Since these initial quantitative demonstrations of the importance of the GIA influence on the secular trends of sea level recorded on modern tide gauges, numerous further analyses have been performed. Among these, the research by Peltier [1996] is especially interesting from the perspective of the present paper.

[21] This analysis of US east coast data demonstrated that, when a model of the GIA process which accurately fit the multimillennial records of Holocene sea level history at
16 sites along this coast extending from Massachusetts to Florida was employed to filter the GIA effect from tide gauge recordings of secular sea level change, the variability in the secular rates of rise was significantly reduced. The regional rate of sea level rise that could be related to climate change was thereby shown to be much more uniform and equal to a value of approximately $0.195 \mathrm{~cm} \mathrm{yr}^{-1}$. The specific aspect of the GIA phenomenon that was removed by the filtering process was the strong rise of sea level along this coast that is induced by the process of glacial forebulge collapse (see Peltier [1998] for a recent review of this feature of the deformation of planetary shape induced by a proximate ice load).

[22] New models for the deglaciation of Great Britain, Greenland and North America, which have been incorporated into the ICE-5G GIA model and which are included in the analyses to be described in this paper, are respectively 


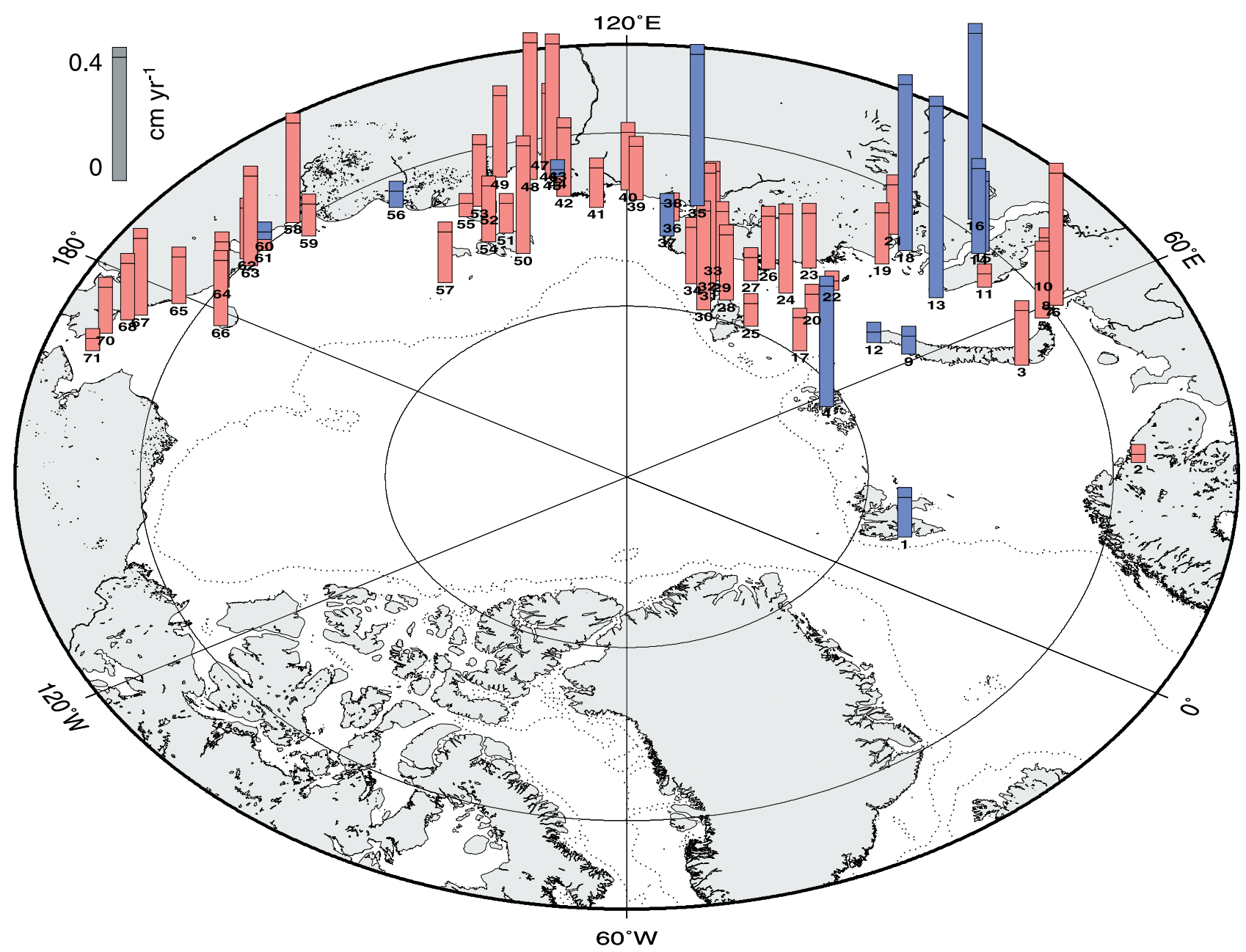

Figure 5. Observed sea level trends $\left(\mathrm{cm} \mathrm{yr}^{-1}\right)$ without corrections (red is positive trend, and blue is negative trend).

discussed by Tarasov and Peltier [2002] and Peltier [2002]. Here we analyze results of modifications that have been made to the ice cover over the Eurasian sector of the model geography. Inspection of Figure 6, which shows the ICE-4G (VM2) GIA prediction for the present-day rate of secular sea level change over the northernmost part of the Northern Hemisphere, demonstrates that this model predicts a substantial rate of present-day sea level fall that extends well to the east of Novaya Zemlya over the entire Kara Sea and the proximate coast of Siberia. This is a consequence of the fact that the ICE-4G model of glaciation history included heavy LGM (Last Glaciation Maximum) ice cover over this entire region. Removal of this ice during deglaciation therefore induces strong postglacial "rebound" of the crust and thus a fall of relative sea level.

[23] In Figure 7a (see also Table 2) we show the observed secular sea level trends as averages over the individual sets of tide gauge records from each of five Arctic seas, the Barents, Kara, Laptev, East Siberian, and Chukchi. Also shown, in Figure $7 \mathrm{~b}$, are the averaged trends for the same regions when the ICE-4G (VM2) model predictions are subtracted from the individual tide gauge trends prior to averaging. Inspection of these filtered results shows that subtraction of the GIA predictions, which are negative for both the Barents and Kara Seas because of the deglaciation that is assumed to have occurred in these regions, dramatically increases the trends, leading to a marked increase in the trend of sea level when averaged over all regions. Rather than exhibiting the lowest trends of all of the Arctic seas for which data are available, these regions are characterized by filtered trends that are the largest of all regions.

[24] However, the ICE-4G model of glaciation history is significantly in error to the east of Novaya Zemlya. This has been demonstrated by the members of the EU sponsored QUEEN project [e.g., Mangerud et al., 2002]. They have analyzed and radiocarbon-dated the position of the LGM margin of the Eurasian ice sheet complex. Their analysis shows that, although the ice sheet extended to the east from the Barents Sea over Novaya Zemlya, the ice sheet did not in fact cover the central Kara Sea nor did it extend onto the Eurasian mainland. In the construction of the ICE-5G (VM2) model [Peltier, 2004] this new information has been taken into account (see Figure 7). The elimination of the heavy ice cover over the Kara Sea sector of the model, together with the additional modifications over the Barents Sea, significantly reduces the predicted rates of relative sea level fall due to GIA on the tide gauges from these regions, thereby leading to much enhanced uniformity of the secular rates of relative sea level rise across all of the Arctic coastal regions from which data are available. 


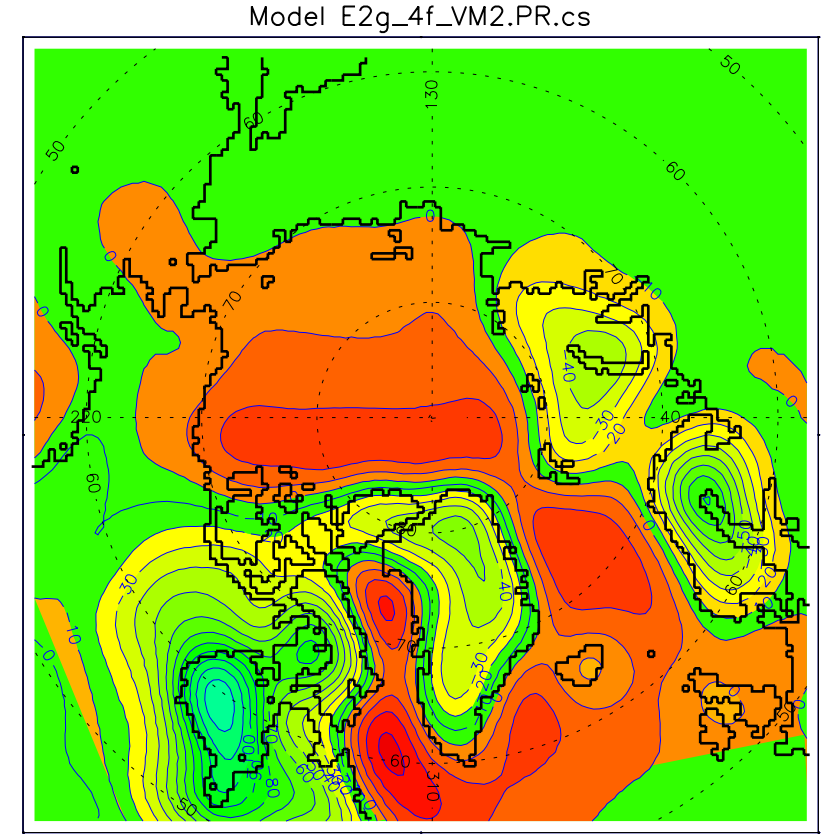

GIA rotes, $\mathrm{cm}$ per 100 yeors

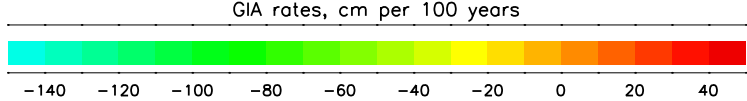

Figure 6. Present-day rate of relative sea level rise as function of geographic position for the ICE-4G (VM2) model [Peltier, 1994, 1996].

[25] It is useful to compare the average rate of secular sea level rise for the Arctic region as a whole to estimates that have been obtained from other regions and globally. By averaging over the filtered tide gauge rates on the most complete time series for the entire period of observations (Table 2) we obtain a value of $0.239 \mathrm{~cm} \mathrm{yr}^{-1}(0.177$ minus -0.062 ), or $0.185 \mathrm{~cm} \mathrm{yr}^{-1}$ for the period 1954-1989 (Table 3). This may be compared to the rate of sea level change of $0.195 \mathrm{~cm} \mathrm{yr}^{-1}$ obtained by Peltier [1996] based upon his analysis of the US east coast data set or to the global estimate of $0.24 \mathrm{~cm} \mathrm{yr}^{-1}$ obtained by Peltier and Tushingham [1989] based upon an EOF analysis in which the ICE-3G model of Tushingham and Peltier [1991] was employed as a GIA filter. Note that the Russian and US east coast records are not of the same length and it is not known as to whether this might distort the meaningfulness of the intercomparison.

[26] A more recent analysis of the global rate based upon the use of the ICE-4G (VM2) model [Peltier, 2002] employed a simple unweighted average of a relatively small number of very long sea level time series and was also discussed by Douglas [2001]. This analysis delivered a global estimate of $0.185 \pm 0.08 \mathrm{~cm} \mathrm{yr}^{-1}$ for the past approximately 70 years, a longer period than that covered by the records from the Siberian seas. The TOPEX/Poseidon altimetric estimate of the global rate of the relative sea level rise (e.g., see A. Cazenave and R. S. Nerem, Presentday sea level change: Observations and causes, submitted to Reviews of Geophysics, 2003) is $0.280 \mathrm{~cm} \mathrm{yr}^{-1}$, but this pertains to an average over only the 1990s.
[27] Now we can conclude that the tide gauge records from the Arctic may be somewhat short to provide a robust estimate of the rate of secular sea level rise for this region. It proves interesting to enquire whether further improved estimates might be obtained by explicitly modeling the various impacts of existing forces in order to better understand the observed time series of sea level. In the following sections of the paper we will therefore consider the influences of atmospheric pressure, river runoff, precipitation and evaporation and the steric effect of volume expansion of water due to warming and freshening of the Arctic seas.

\section{Adjustment for Meteorological Factors}

[28] In order to estimate the influence of meteorological factors on sea level change, we have employed a set of atmospheric parameters from different sources. Observations from a number of meteorological stations of sea level atmospheric pressure (SLP) were extracted for the region from the National Center for Environmental Prediction (NCEP) and National Center for Atmospheric Research (NCAR) archives. Further estimates have been made using results from 2-D barotropic and 3-D baroclinic coupled iceocean models driven by different forcing included in the design of special numerical experiments.

\subsection{Sea Level Atmospheric Pressure}

[29] Corrections for atmospheric pressure variations are known to be essential for studies of seasonal and interannual variability of mean sea level, although it has only recently

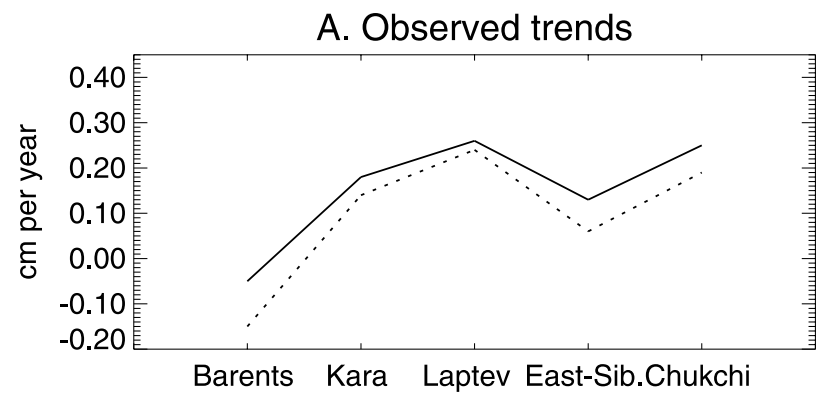

\section{B. Trends corrected for GIA}

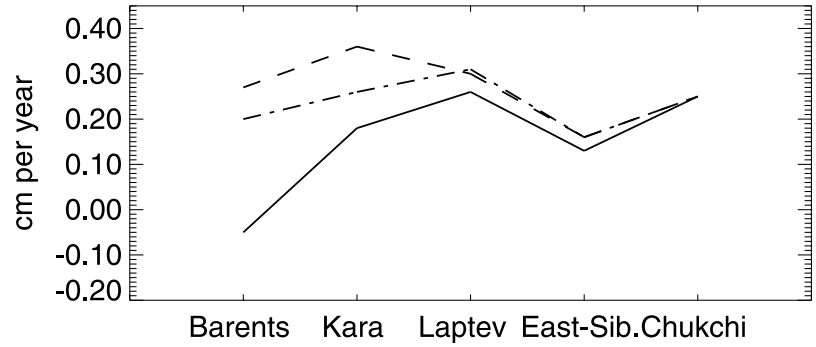

Figure 7. Trends from (a) observed and (b) GIA-corrected sea level data for the Arctic seas. Note that in Figure 7b, trends are shown for the whole period of observations. Solid and dotted lines show trends for the entire period of observations and for 1954-1989, respectively. Dashed and dot-dashed lines show trends corrected for GIA from models ICE-4G(VM2) and ICE-5G(VM2), respectively. 


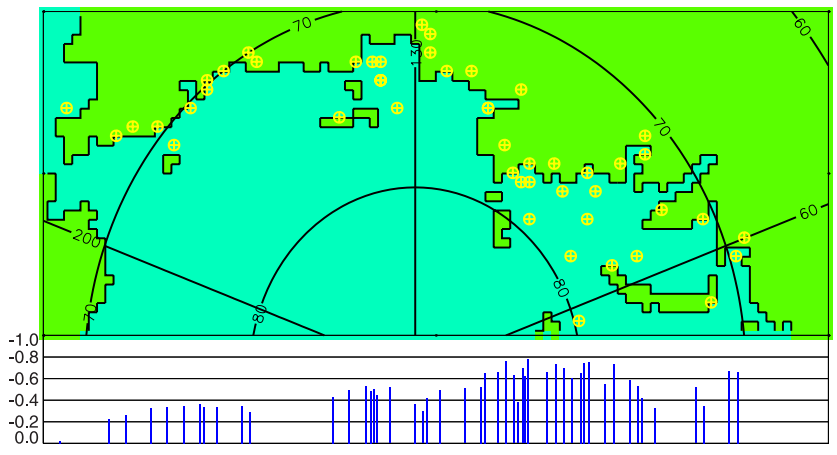

Figure 8. Correlation between monthly sea level and sea level atmospheric pressure at coastal stations. Bars show correlation coefficients for shown stations. Vertical axis denotes correlation coefficient.

[IPCC, 2001] been pointed out that these changes are important for analysis of secular changes in sea level because their long-term trends are noticable. For the Arctic conditions where variability in sea level atmospheric pressure is substantial this factor is very important. For instance, Walsh et al. [1996] concluded that the Arctic sea level pressure revealed a significant decrease in the period 19791994. Changes in the annual means were larger in the central Arctic than anywhere else in the Northern Hemisphere. The effect of this continuing sea level pressure fall could be responsible to some degree for the sea level rise that we have inferred to be occurring over the Arctic Ocean.

[30] To begin to assess this possibility, we have analyzed the variability of sea level pressure (SLP) at Arctic coastal stations and correlated the monthly SLP with monthly mean sea level changes. Figure 8 shows that sea level correlates very well with SLP and that maximum correlation is observed at the stations in the eastern Kara Sea (correlation coefficients are less than -0.70 ). The correlation is negative because as SLP increases sea level decreases such that a $1 \mathrm{hPa}$ change in SLP corresponds approximately to a $-1 \mathrm{~cm}$ change in sea level (inverted barometer effect). Also, the correlation is similar at nearby stations which gives some confidence in the results. The correlation between sea level and SLP gradually decreases from the Kara Sea toward both the Norwegian and Chukchi Seas, thus demonstrating the role of this factor in sea level variability for each region.

[31] Figure 9 shows trends in SLP $\left(\mathrm{hPa} \mathrm{yr}^{-1}\right)$ calculated at locations of meteorological stations for 1948-1997 and 1954-1989 from different gridded data sets. These data sets are available at the National Center for Atmospheric Research and include Trenberth's data set $\left(5^{\circ} \times 5^{\circ}\right.$ monthly SLPs for 1899 to present), NCAR/NCEP octagonal grid for 1948-1997 data set, and NCAR/NCEP reanalysis data for 1948 to present. This figure also shows trends calculated on the basis of SLPs observed at a number of stations from which information is available. Two periods are chosen because we intend to investigate the dependability of calculated trends on the period of analysis. The period 1954-1989 is the period for which sea level trends were calculated for our most complete time series. The period 1948-1997 is analyzed because this is a common period covered by the different SLP data sets that were available for our analysis, and also covers the most recent history of
SLP change in the Arctic. There are some common features in the SLP trends obtained for these two periods. For example, largest SLP trends are located in the northern parts of the seas and they diminish toward lower latitudes.

[32] Our analysis of longer time series of SLP, which are available for some stations from the 1920s onward, reveals a detectable negative SLP trend only after 1950 (not shown here). Trends calculated on the basis of measurements made at stations are always larger than trends obtained from the gridded data. This is probably a result of smoothing of information during interpolation procedures. One also sees that the behavior of the SLP trends depends on the period of analyses and this is consistent with the behavior of sea level trends: trends calculated for 1954-1989 are smaller than for the period $1948-1997$.

[33] The spatial structure of the SLP trends over the entire Arctic is shown in Figure 10. There are large differences in the SLP trends from different data sources in the central Arctic, but for the coastal areas where tide gauges are located these trends do not differ significantly because these regions are better represented by SLP observations.

[34] During the most recent decade (1989-1997), the Arctic atmospheric regime has differed substantially from previous decades; so much so that SLP trend estimates based on the data including and excluding the last decade are strikingly different. For the period 1954-1989, SLP has a positive trend in the Canadian Arctic with a rate of about $0.02-0.04 \mathrm{hPa} \mathrm{yr}^{-1}$, whereas in the Eurasian Basin and the Greenland Sea there was a negative trend. For the period of all available observations (excluding the most recent 4 years), the SLP trend is negative for the entire Arctic except for shelf areas of the East Siberian, Chukchi, and Beaufort Seas. Sea level should rise in these regions because of the inverted barometer effect.

\subsection{Adjustment for Wind Forcing}

[35] In order to assess the role of wind and several other factors we have employed a 2-D barotropic coupled iceocean model. This model takes into account wind effects, sea ice influence, the inverted barometer effect, variable river discharge and variable inflow of the Pacific waters through Bering Strait. It does not take into account changes
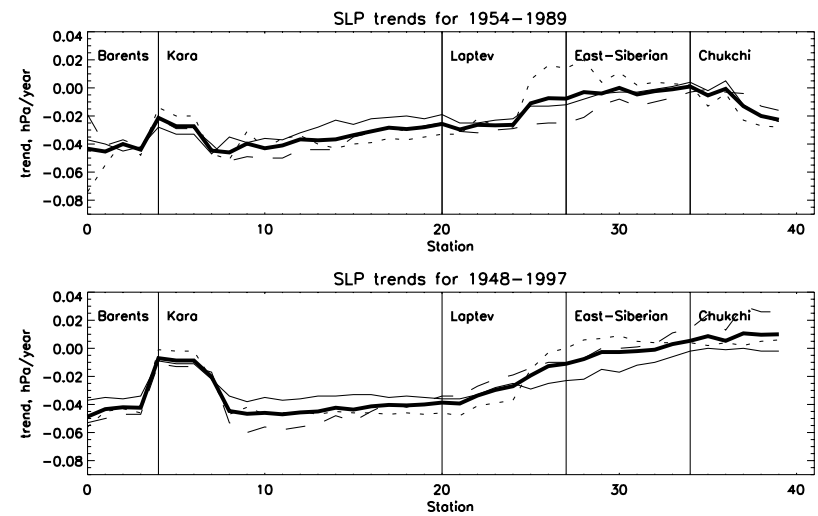

Figure 9. SLP trends from different sources at the locations of coastal stations. Solid thin, dotted, and dashed lines show trends from Trenberth, reanalysis, and analysis SLP data sets, respectively. Thick solid line shows mean trend from all these sources. 


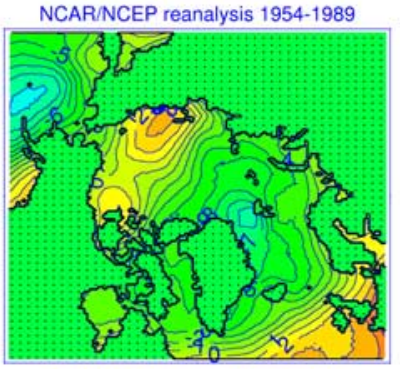

NCAR octagonal grid 1954-1989

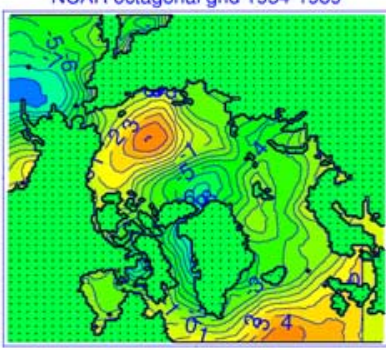

Trenberth data set 1954-1989

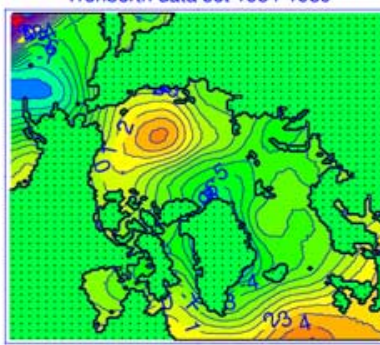

SLP trend, hPa per 100 years
NCAR/NCEP reanalysis 1948-1997

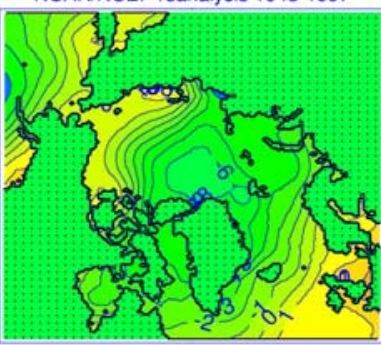

NCAR octagonal grid 1948-1997

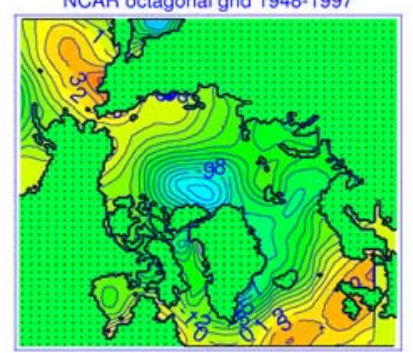

Trenberth data set 1948-1997

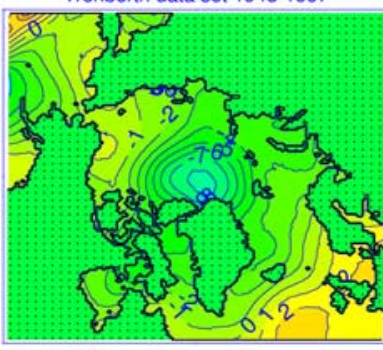

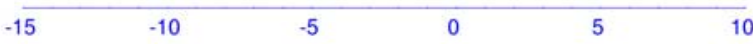

Figure 10. SLP trends from different data sources.

in sea level associated with changes in ocean temperature and salinity (steric effects) and changes in water exchange with the Atlantic Ocean due to thermohaline factors. At each point of this "Atlantic" boundary of the model we apply radiation conditions. In the past we have successfully used this model for the calculation of storm surges [Proshutinsky, 1993], as well as to describe the wind-driven circulation in the Arctic Ocean [Proshutinsky and Johnson, 1997]. For the present study, sea level variability and sea ice drift were simulated, and the evolution of the ocean circulation was integrated for the period 1948-2002 using NCAR/NCEP 6-hour SLP reanalysis data. Several numerical experiments were carried out. In the first experiment we employed full model forcing (inverted barometer effect, wind stresses, drifting and shore fast ice, and monthly changing river runoff) in order to evaluate the total role of winds and variability in SLP upon the sea level dynamics. Figure 11 (left) shows observed and simulated data for several stations in the Arctic seas.

[36] The correlation between observed and simulated annual sea levels is relatively high (on average it is 0.61) and for some stations it reaches 0.75 . When we adjust observed sea levels for the influence of the factors mentioned above (by subtracting the simulated sea levels from the observations), the standard deviation of the adjusted annual time series decreases from $6.40 \mathrm{~cm}$ to $5.89 \mathrm{~cm}$ for all stations and from $6.77 \mathrm{~cm}$ to $5.59 \mathrm{~cm}$ for stations for which the duration of observations exceeded 50 years. The spatial distribution of the sea level trend for the period 1948-1997 (based on results of the full "barotropic" forcing simulation) is shown in Figure 12 (top left). Maximum changes for this period occurred in the central Arctic where the sea level trend is approximately $0.08 \mathrm{~cm} \mathrm{yr}^{-1}$.

[37] A set of numerical experiments was designed to investigate the roles of wind and inverted barometer effect. In order to assess the role of wind forcing, we ran our model for the period 1948 to present under the influence of wind stresses only (without inverted barometer effect and river runoff). The role of the inverted barometer effect was similarly assessed but in this case all forcing factors except terms responsible for the inverted barometer effect in the model equations were excluded.

[38] Figure 12 (bottom) illustrates the role of meteorological forcing (wind and inverted barometer effect respectively). Wind forcing is primary important in shallow shelf regions where the wind energy is sufficient to generate detectable changes in sea surface heights. The maximum trend induced by this effect occurs in the Laptev, East Siberian, and Chukchi Seas. In the deep ocean regions, the wind effect is negligible and the inverted barometer effect prevails. Model results for the assessment of the role of the inverted barometer effect (Figure 12 (bottom right)) correspond very well to the sea level trend shown in Figure 10 (right). This implies that the model solution is quite accurate and that for timescales longer than 1 month


Figure 11. Observed (blue) and simulated (red (with inverted barometer effect) and black (without inverted barometer effect)) sea surface heights (left) 2-D and (right) 3-D model results. 
Full forcing with fast ice
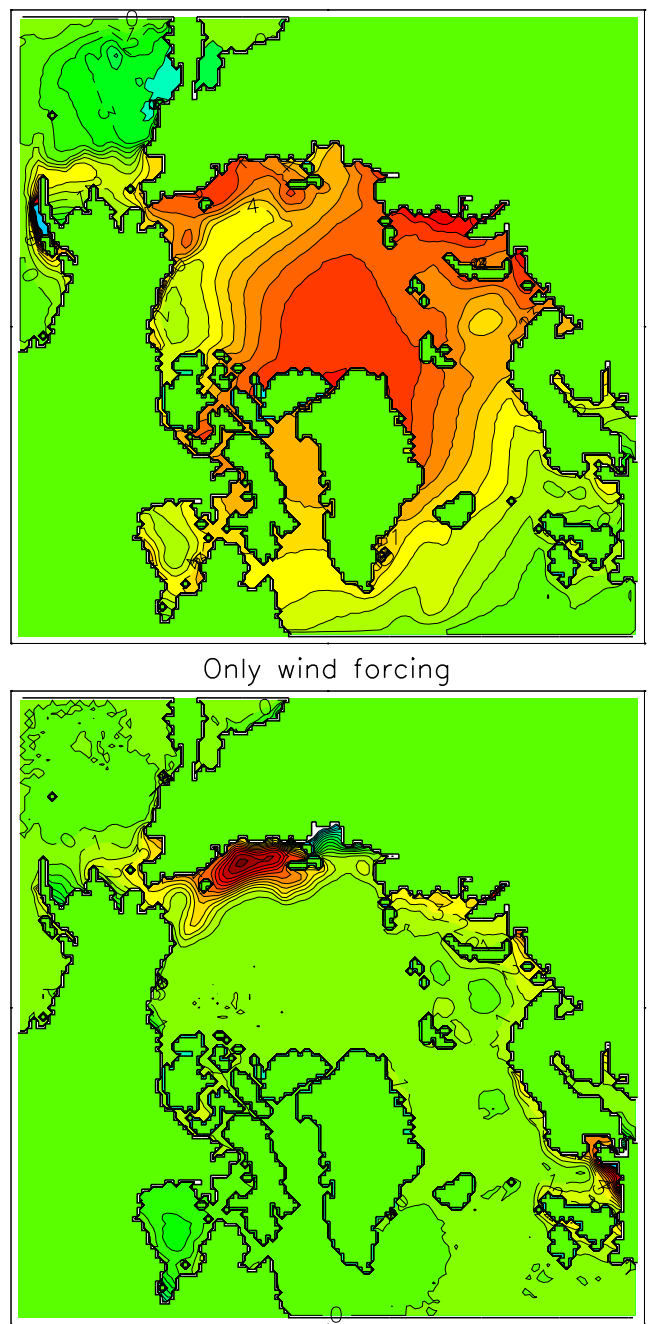

Full forcing and no fast ice

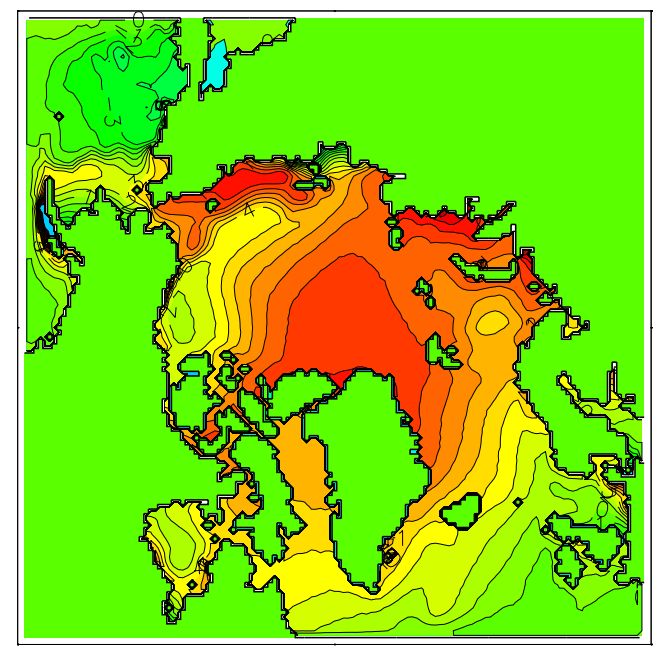

No wind forcing

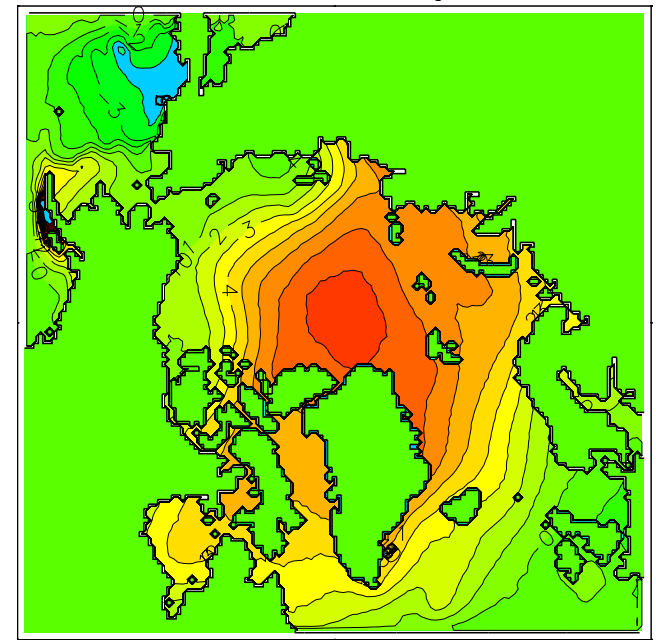

per 100 years

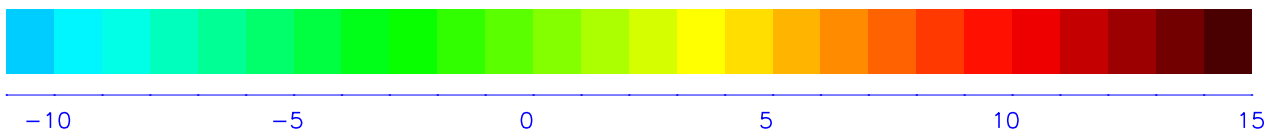

Figure 12. Sea surface height trends associated with different forcing based on numerical experiments with the 2-D coupled ice-ocean model (1948-1997).

the inverted barometer effect can be used for sea level trend adjustments. Sea level trends associated with the wind and inverted barometer forcing are also shown in Table 3.

\subsection{Precipitation and Evaporation}

[39] Our barotropic 2-D and baroclinic 3-D models do not include interannual variability of precipitation $(\mathrm{P})$ and evaporation (E) (hereafter, we will use the term "precipitation minus evaporation" (P-E), in order to investigate the net effect of these parameters) because for the purpose of the 3-D model experiments P-E is input as a climatological mean. It is therefore important to estimate the role of P-E changes over the Arctic on sea level variability.

[40] Monthly P-E data were compiled from daily NCEP/ NCAR reanalysis precipitation data and latent heat flux data for the period 1948 to present. The latent heat flux data were converted into evaporation by dividing it by the latent heat of evaporation $\left(\mathrm{L}=2.5106 \mathrm{~J} \mathrm{~kg}^{-1}\right)$. The annual P-E anomalies in the Arctic Ocean are shown in Figure 13 (inset). The anomalies are for the most part limited to $200 \mathrm{~km}^{3} \mathrm{yr}^{-1}$ with the exception of the early period when data may have been less reliable. These values represent about $10 \%$ of the net annual precipitation over the Arctic. The data show a negative trend in P-E over the Arctic Basin with a rate of about $-4 \mathrm{~km}^{3} \mathrm{yr}^{-1}$. On the other hand, there is practically no trend in P-E after 1960. In order to assess the role of the change in P-E, we ran the 2-D model under the influence of P-E forcing only (without wind stresses, inverted barometer effect, and river runoff). All of the open boundaries of the model had a radiation boundary condition prescribed. Figure 13 shows sea level trends associated with P-E for the period 1954-1989. For the coastal regions of 


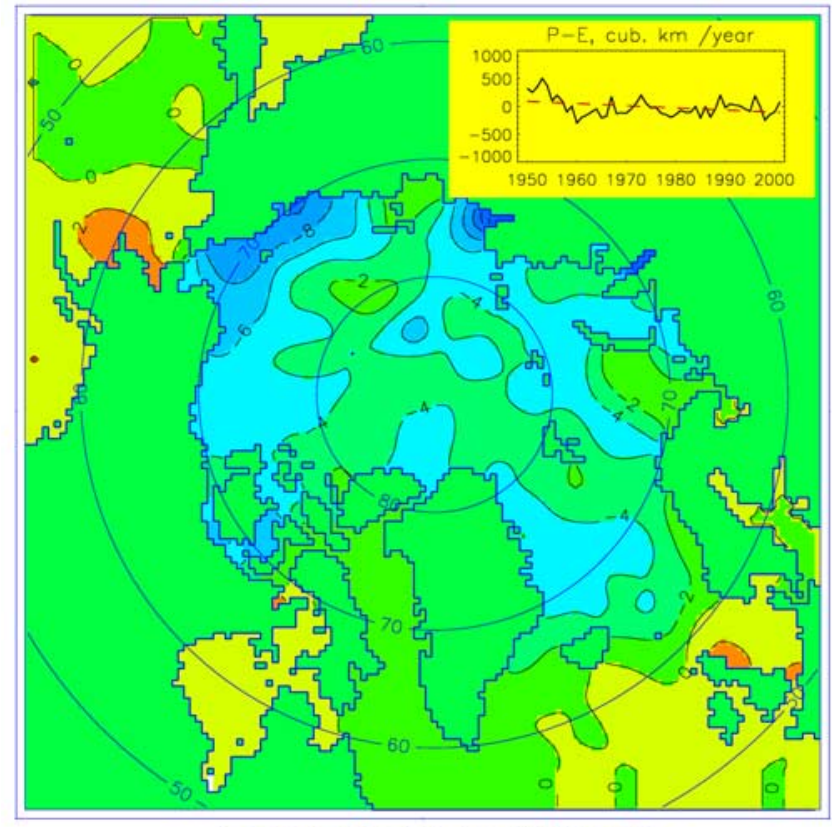

Sea level trend, $\mathrm{cm}$ per 10000 years

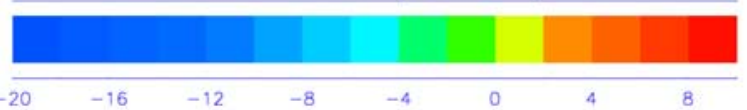

Figure 13. Sea level trends associated with P-E from the 2-D coupled ice-ocean model run (1954-1989). (inset) Annual anomalies of P-E (solid line) and their trend (dashed line) calculated from NCAR/NCEP reanalysis data set.

the Siberian seas, this trend is negative and on average is approximately $0.002 \mathrm{~cm} \mathrm{yr}^{-1}$, which is one order of magnitude smaller than the trends due to wind forcing and the inverted barometer effect.

\section{River Runoff}

[41] Variability in river discharge could be an important factor for understanding Arctic sea level change. Figures 2-4 (stations influenced by river runoff) show that sea level increases significantly in the period June-July at many stations located in the vicinity of river mouths because of increased river discharge associated with snow melting. Interannual variability in river discharge is relatively small and in previous publications [Dvorkin, 1991; Vorobyov et $a l ., 2000]$ this factor was not taken into account. Results presented in recent publications based on the synthesis of river-monitoring data [e.g., Peterson et al., 2002] reveal that the average annual discharge from the six largest Eurasian rivers to the Arctic Ocean increased by 7\% from 1936 to 1999 and this means that the annual rate of increase was $2.0 \pm 0.7 \mathrm{~km}^{3} \mathrm{yr}^{-1}$.

[42] In order to assess the role of river discharge on sea level variability, we have carried out two numerical experiments. In the first experiment we ran our 2-D coupled iceocean for the period 1948-2002 with all possible forcing applied, together with monthly river discharge. Figure 14a shows significant improvement in model results when real river runoff is added as a forcing factor. In the second experiment, we ran the model with river runoff only. All other forcing factors such as wind forcing, and the inverted barometer effect, etc., had zero influence.

[43] Figure 14b shows vectors of vertical mean currents associated with river runoff in winter and summer. Figure $14 \mathrm{c}$ also shows that the direct effect of river runoff (the dynamic effect and the effect associated with the increase of water volume in the ocean) at interannual and longerterm scales is relatively small and that the sea level trend associated with this river inflow in terms of the barotropic effect is positive but very small and practically negligible.

[44] It is interesting that the small negative sea level trend associated with P-E over the Arctic Ocean is compensated by a small positive sea level trend related to increasing river runoff. On the other hand, we understand that the accuracy of P-E reanalysis data over the open ocean, and the river discharge data, is not sufficient to allow robust conclusions to be drawn. An investigation of baroclinic effects related to the water salinity and temperature change due to different factors such as river runoff, precipitation, evaporation, sea ice melt, and freeze-up are discussed in the following section.

\section{Steric Effects}

[45] In order to investigate the sea level variability generated by changes in thermohaline forcing, Pavlov and Pavlov [1999] and later Proshutinsky et al. [2001] employed a 3-D diagnostic baroclinic model with a free surface. A set of diagnostic simulations of water circulation and sea level fields was carried out to calculate decadal mean patterns of sea level representing the 1950s, 1960s, 1970s, and 1980s using only water temperature and salinity fields for these decades from the Joint U.S.-Russian Atlas of the Arctic Ocean [Environmental Working Group $(E W G)$, 1997, 1998]. The results of this work showed that observed decadal sea level variability (change from the 1950s to 1980s in sea level time series averaged over decades) was well correlated with the simulated sea level change due to the variability of water temperature and salinity. However, it is extremely difficult to evaluate the sea level trend associated with water temperature and salinity changes on the basis of only 4 data points for each station (one per decade) in these time series. Furthermore, the most recent changes in oceanic parameters are not reflected in these data sets.

[46] In the current study, we have therefore investigated sea level variability using a 3-D coupled ice-ocean model [Häkkinen and Mellor, 1992]. The model covers the entire Arctic and more than half of the Atlantic Ocean extending from the Bering Strait in the Arctic Ocean to $15^{\circ} \mathrm{S}$ in the Atlantic Ocean with a resolution of $7 / 10^{\circ}$ along meridians, and $9 / 10^{\circ}$ along parallels. The initialization of a 20 -year quasi-equilibrium run was started from an annual average hydrographic climatology of the World Ocean Atlas 1998. The vertically averaged transports at oceanic lateral boundaries were specified to be $0.8 \mathrm{~Sv}\left(1 \mathrm{~Sv}=1.0 \times 10^{6} \mathrm{~m}^{3} \mathrm{~s}^{-1}\right)$ in the Arctic Ocean through the Bering Strait and $0.8 \mathrm{~Sv}$ out of the model domain at $15 \mathrm{~S}$. At the northern (Bering Strait) and southern $\left(15^{\circ} \mathrm{S}\right)$ model domain boundary the water salinities and temperatures were relaxed to monthly climatological values.

[47] The model is forced with monthly climatological data computed from the NCEP/NCAR reanalysis for the 
a Antipaiuta Correl.: (0.30) (0.68)

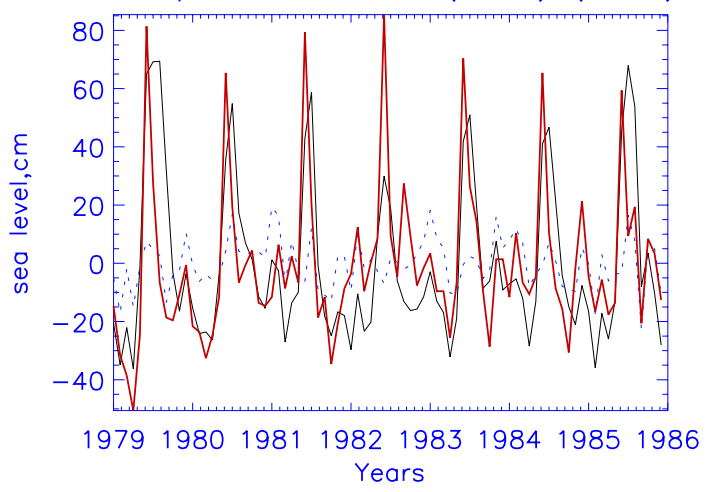

b
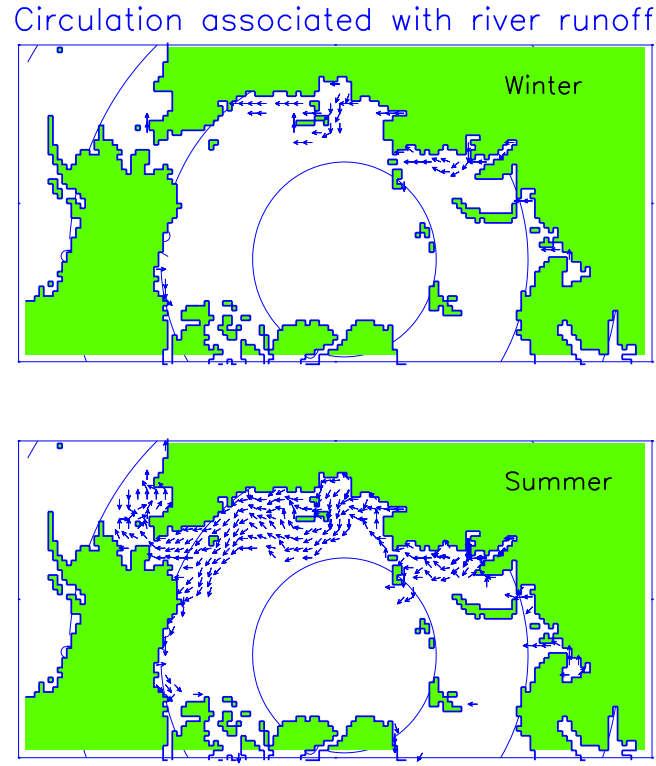

Sopochnaia Correl.: (0.28) (0.87)

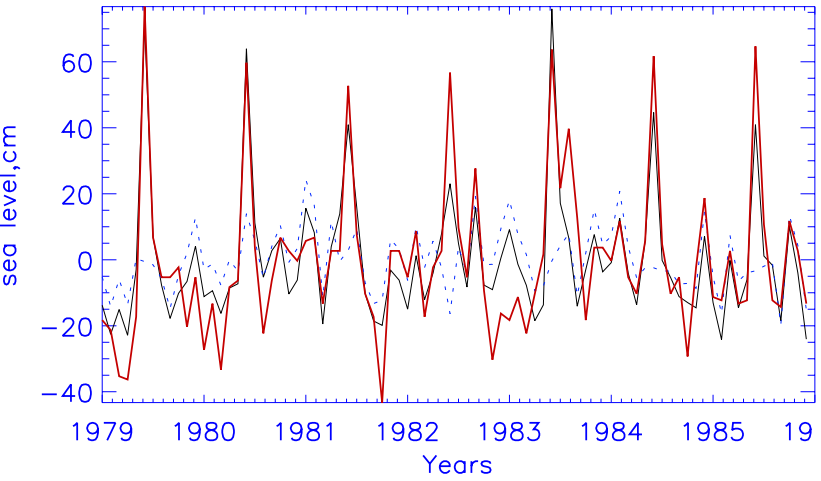

c Sea level trend due to river runoff

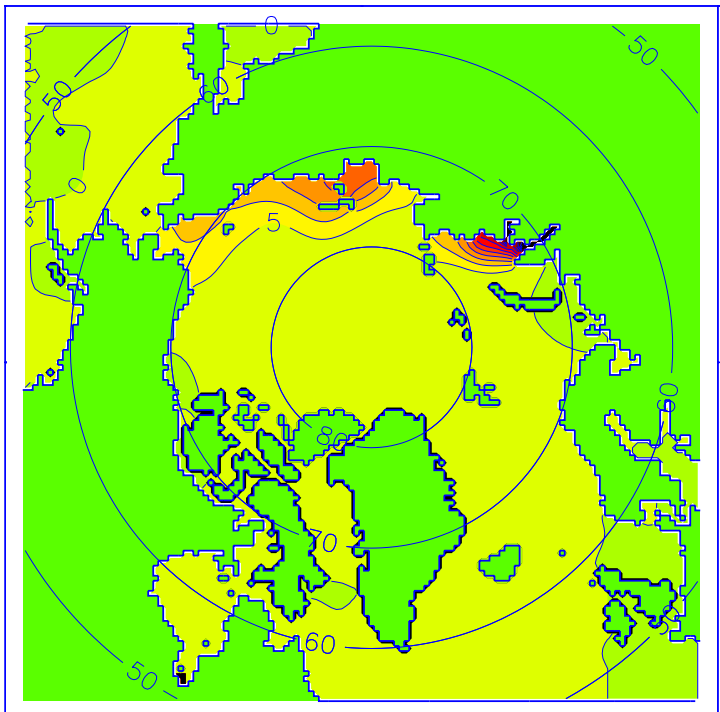

Sea level trend, cm per 10000 years

$\begin{array}{lllllll}-5 & 5 & 15 & 25 & 35 & 45 & 55\end{array}$

Figure 14. (a) Sea level time series, (b) mean ocean circulation, and (c) simulated sea level trend associated with river runoff. Figure 14a shows observed (black line) and simulated (dotted blue line (without river runoff) and red solid line (with river runoff)) for two stations of the Yenisey River. Correlation coefficients between observed and simulated (without and with river runoff, respectively) sea level are shown in titles of these figures. Figure 14b shows barotropic water circulation associated with the inclusion of river runoff to the model, and Figure 14c shows sea level trends associated with river discharge based on 1954-1989 model simulation results.

first 20 years, after which monthly varying reanalysis fields (wind stress, wind speed, air temperature, and specific humidity) are phased in during a period of 4 years, by first appending COADS monthly anomalies [da Silva et al., 1994] to the reanalysis climatology from 1945-1947 and then blending COADS and reanalysis data during 1948. From 1949 to 2002 the forcing is solely NCEP/NCAR reanalysis data.

[48] The cloudiness and P-E fields, and river runoff are climatological means throughout model simulations. The surface boundary condition for salinity uses a virtual flux of salt modified by the brine/meltwater flux in the ice covered ocean. Similarly, the river runoff represents a virtual flux of salt. For a heat exchange, a bulk formulation is adopted where the heat fluxes are a function of the oceanic surface quantities. The model simulated data are monthly averaged. One sees that the model does not take into account the inverted barometer effect and variable fresh water inflows associated with river runoff, P-E, and Bering Strait inflow. Figure 11 (right) shows the simulated results. Model results are in better agreement with observations than the simulated results from the 2-D barotropic model, especially when we correct these data for the inverted barometer effect.

[49] The correlation between observed and simulated annual sea levels on average is 0.70 and it is higher than the correlation between observed and simulated sea level time series from our 2-D model. When we subtract the simulated 3-D model sea levels (corrected for the inverted 
3-D model. 1951-2001

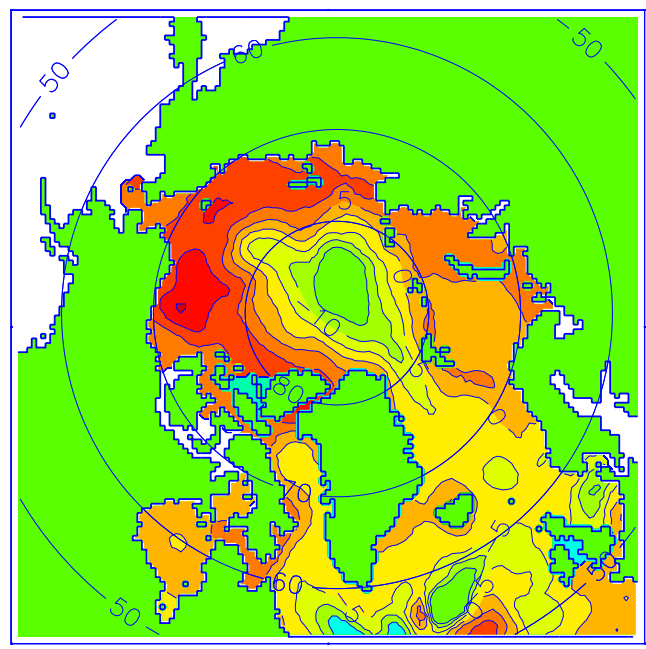

Corrected, 1951-2001

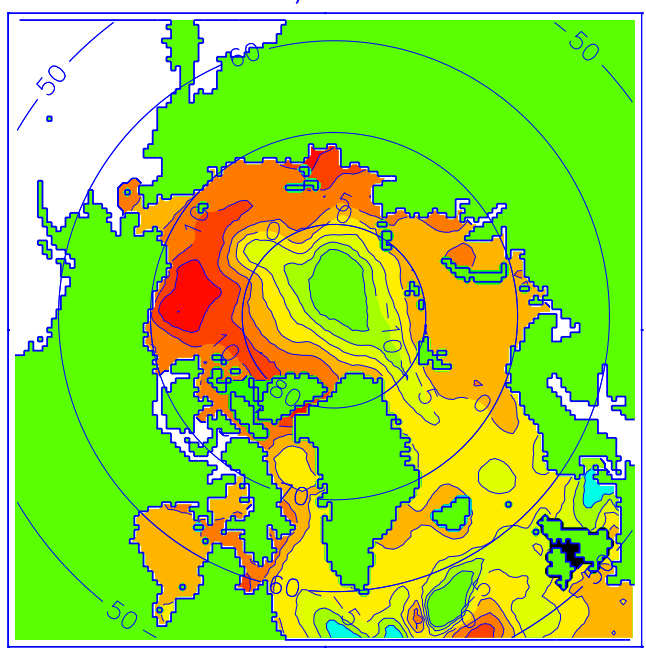

3-D model. 1954-1989

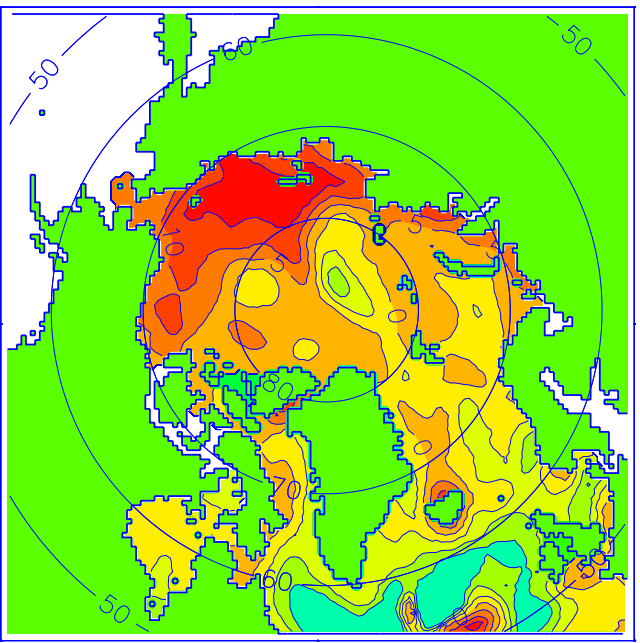

Corrected, 1954-1989

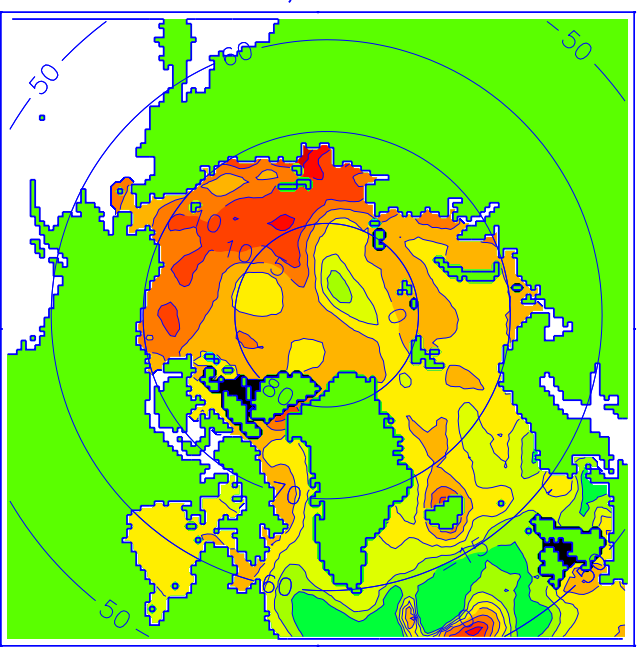

Sea level trend, $\mathrm{cm}$ per 100 years

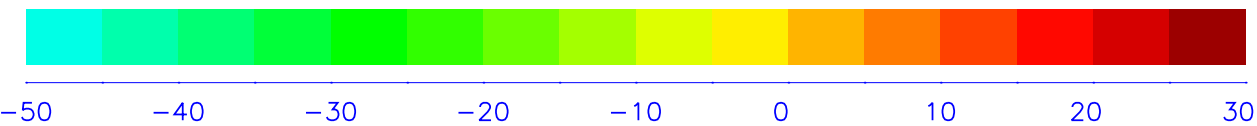

Figure 15. (top) Sea level trend from 3-D model results for (left) 1951-2001 and (right) 1954-1989. (bottom) Sea level trend from 3-D model results corrected for wind effect for (left) 1951-2001 and (right) 1954-1989.

barometer effect) from observations, the standard deviation of the adjusted annual time series decreases from $6.40 \mathrm{~cm}$ to $4.50 \mathrm{~cm}$. Unfortunately, there are many peaks in the observational data that models do not reproduce. It seems that these extrema are real because many stations consistently reproduce them. Some of these peaks are reproduced by the model at some stations, but for other regions the model fails to simulate them. This is probably associated with regional conditions (regional wind patterns which NCAR/NCEP reanalysis data do not resolve) or probably in some years these regions have unusual sea ice conditions (more or less developed shore fast ice, for example), which is not taken into account in the model.

[50] Some results for a fast ice experiment are shown in Figure 12. In coastal regions (compare the distribution of sea level trends in the Laptev and East Siberian Seas with and without fast ice) the fast ice influences sea level variability, but it practically does not influence sea level changes in the deep ocean. Therefore sea level time series collected at coastal stations have variability induced by the fast ice extent and we think that this problem should be investigated in greater detail in the future.

[51] Figure 15 (top) shows sea level trends calculated from annual sea levels from the 3-D model results. These trends depend significantly on the period of calculation but in general the model predicts a sea level rise in the coastal regions and a sea level fall in the Nansen and Amundsen basins. This is probably related to the increase of advection of Atlantic Water with a relatively high salinity into the area after the 1980s. Positive trends in sea level over shelves are 
the result of a redistribution of river runoff due to an increase of the cyclonicity of atmospheric forcing [Proshutinsky and Johnson, 1997]. Figure 15 (top) shows that in the period 1954-1989, the maximum trend in sea level rise was located in the East Siberian Sea and for the period 1951-2001 it shifted to the Beaufort Sea. This is consistent with our conclusion [Proshutinsky et al., 2001] that in the cyclonic circulation regime the freshwater flux from Arctic rivers propagates further east and the area of water salinization (and related sea level decrease), increases over the Amundsen and Nansen Basins.

[52] Sea level trends associated with steric effects are shown in Figure 15 (bottom). This pattern was calculated by subtracting wind effect from our 3-D model results. The general pattern of the spatial distribution of sea level change does not differ significantly from Figure 15 (top) but trends along the coastline decrease because wind action is more pronounced along the shallow shelves (Figure 12).

\section{Discussion}

[53] In the preceding sections of this paper we have endeavored to answer the questions formulated in the introduction to this paper, namely: "What is the rate of sea level rise in the Arctic Ocean?", and "What are the impacts of different factors upon the observed trend in sea level?" To begin with, we reiterate the results of these analyses for the 40 stations with most complete time series and for the period 1954-1989. Figure 16 (see also Table 3) summarizes these trends by showing them for all seas. The range of observed trends (black solid line in Figure 16) is from -0.25 to $0.50 \mathrm{~cm} \mathrm{yr}^{-1}$. The mean trend is $0.123 \mathrm{~cm} \mathrm{yr}^{-1}$ for $1954-$ 1989. After corrections for the process of glacial isostatic adjustment, this mean trend becomes $0.185 \mathrm{~cm} \mathrm{yr}^{-1}$. The trend associated with all environmental factors which were taken into account in this study is $0.137 \mathrm{~cm} \mathrm{yr}^{-1}$. The statistical $95 \%$ confidence interval for the mean estimate is $\pm 0.012 \mathrm{~cm} \mathrm{yr}^{-1}$. Therefore the difference between sea level trend corrected for GIA $\left(0.185 \mathrm{~cm} \mathrm{yr}^{-1}\right)$ and simulated sea level rise $\left(0.137 \mathrm{~cm} \mathrm{yr}^{-1}\right)$ is $0.048 \mathrm{~cm} \mathrm{yr}^{-1}$ and could be attributed to sea level change in the area outside of the Arctic Ocean. We speculate that the $0.048 \mathrm{~cm} \mathrm{yr}^{-1}$ residual rate is very nearly equal to the estimates of the contribution of small ice sheets and glaciers $\left(0.02-0.04 \mathrm{~cm} \mathrm{yr}^{-1}\right)$ $[I P C C, 2001]$ plus the cumulative effect of the sea level change due to contribution of Greenland and Antarctica $\left(0.00-0.05 \mathrm{~cm} \mathrm{yr}^{-1}\right)[I P C C, 2001]$ over the 20th century, as a result of long-term adjustment to past climate changes.

[54] Table 3 answers the second question concerning the sources of sea level rise in the Arctic Ocean. There are two major contributors. First, sea level rises because of the steric effect of volume expansion of Arctic Ocean, and the influence of freshening is probably the most important factor, because salinity plays the dominant role in the Arctic Ocean in controlling the variation of water density. Our simulations with the 3-D baroclinic model demonstrate that the steric effect of ocean expansion $\left(0.064 \mathrm{~cm} \mathrm{yr}^{-1}\right.$ (in order to calculate this "pure" steric effect we have subtracted the sea level trend associated with wind action from the sea level trend computed using the 3-D baroclinic model) contributes approximately $35 \%$ to the net rate of sea level rise in the Arctic Ocean.

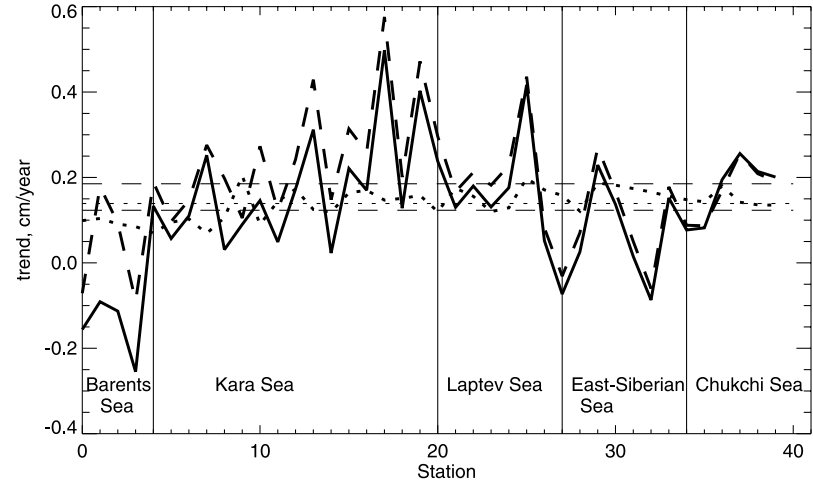

Figure 16. Sea level trends for 1954-1989. Solid line shows trends from observations. Dashed line shows observed trends corrected for GIA process, and dotted line depicts variability of trends associated with the inverted barometer effect, river runoff, and steric effects. Thin horizontal dashed and dotted lines show mean trends for all seas.

[55] The IPCC [2001] analysis of the factors contributing to sea level change suggests that in the World Ocean, the sea level trend associated with ocean thermal expansion has a central value of $0.05 \mathrm{~cm} \mathrm{yr}^{-1}$ within a range $0.03-0.07 \mathrm{~cm} \mathrm{yr}^{-1}$ for the 20th century. The estimate for the Arctic Ocean presented in the IPCC report is based on the observational evidence that in the past decade the temperature of the Atlantic layer in the Arctic was about $1^{\circ}$ higher than in the EWG climatology [Quadfasel et al., 1991; Carmack et al., 1997; Swift et al., 1997]. Therefore, following the IPCC discussion, there should be an increase of sea level from 1 to $2 \mathrm{~cm}$ during the last 10 years, or $0.1-0.2 \mathrm{~cm} \mathrm{yr}^{-1}$.

[56] We assume that our model results provide a significantly better estimate because the model shows sea level change under the influence of both thermal expansion and expansion due to salinity. The later influence not having been taken into account in IPCC considerations.

[57] The second largest factor contributing to the rate of sea level rise in the north polar region is related to the decrease of SLP over the Arctic Ocean $\left(0.056 \mathrm{~cm} \mathrm{yr}^{-1}\right.$, or approximately a $30 \%$ contribution to the sea level trend). In comparison, the IPCC suggests that for the World Ocean the sea level trend associated with the changes in SLP is of order $\pm 0.02 \mathrm{~cm} \mathrm{yr}^{-1}$. In the Arctic, this factor is much more pronounced than it is in the rest of the globe.

[58] The third contribution to the sea level rise in the Arctic involves wind action and the increase of cyclonicity of atmospheric circulation and wind speed over the Arctic Ocean leading to sea level rise at a rate of approximately $10 \%$ of the total, but which varies significantly from region to region such that in the Laptev and the East Siberian Seas it can contribute up to $25 \%$ of the observed sea level change. Interestingly, in the Laptev Sea this factor causes a decrease of sea level $\left(-0.032 \mathrm{~cm} \mathrm{yr}^{-1}\right)$. IPCC does not consider changes in sea level due to wind effects, probably because these effects are local and change significantly from region to region. On the other hand, our study demonstrates that changes in the atmospheric circulation and associated changes in wind speed and direction should be taken into account. 

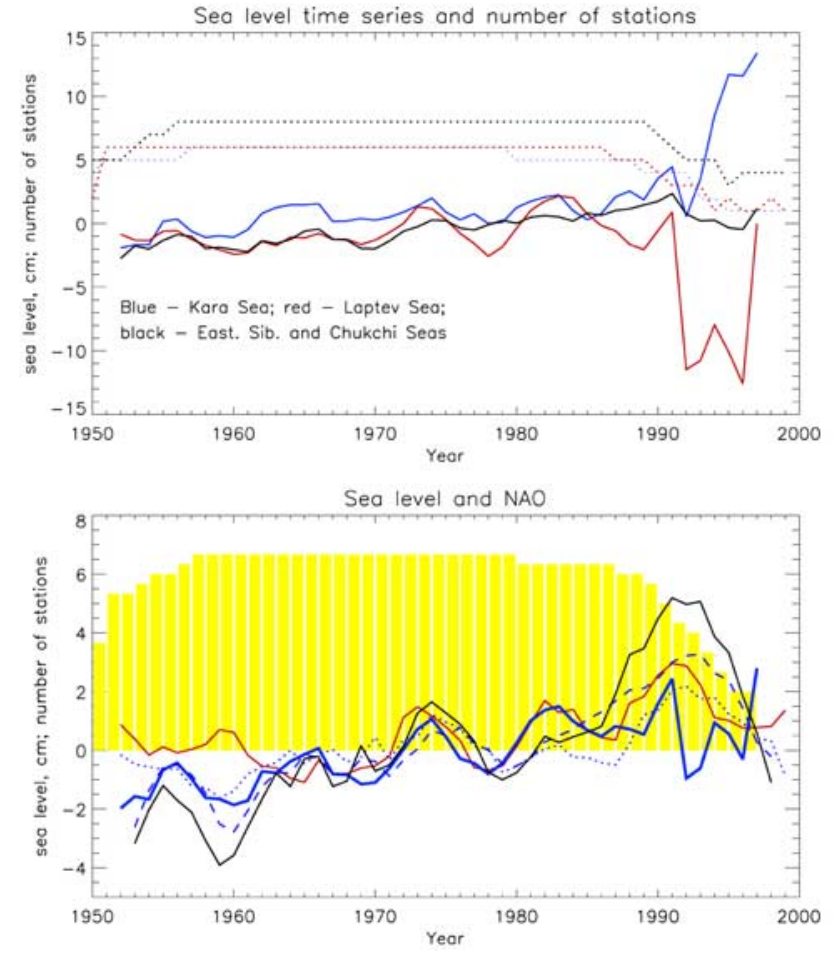

Figure 17. Sea level decadal variability. (top) Mean sea level time series for different seas. Dotted lines denote number of coastal stations used for averaging. (bottom) Mean time series for all seas (thick blue line, 5-year running mean). Mean number of stations used in each sea is shown by yellow bars. Red thick line shows 5 -year running mean North Atlantic Oscillation index. Thin dashed line shows sea level variability from 3-D model, and dotted blue line shows variability of sea level due to inverted barometer effect. Solid black line shows sea level from 3-D model corrected for the inverted barometer effect.

[59] The cumulative effect of sea level rise due to the increase of river runoff and to the negative trend in P-E is close to 0 . The process of glacial isostatic adjustment is primarily important in the Barents and Kara Seas and to some degree also in the Laptev Sea. In the Laptev, East Siberian, and Chukchi Seas this factor is not a dominant influence.

[60] Figure 17 shows the average time series (corrected for GIA) of sea level based only on the data from coastal land stations which are not influenced by river runoff. Separate curves (Figure 17 (top)) are shown for each region respectively for the Kara, Laptev, East Siberian, and Chukchi Seas. It can be seen that there exists decadal variability in each time series with a magnitude of approximately $2 \mathrm{~cm}$ before 1990 . The decadal oscillation is more pronounced in the Laptev Sea than in the other regions. Sea levels in each area oscillate in phase and sea level trends are more or less identical. After 1990 the sea level behavior differs significantly among regions, and this is most probably because the number of stations available for data averaging decreases significantly. Many observational programs in the Arctic were interrupted after 1989 and we assume that these data sets are not representative after
1989-1990. Figure 17 (bottom) shows a mean sea level curve for all regions and sea level seems to correlate surprisingly well with the North Atlantic Oscillation index (red solid line) after about 1963. Before 1963 this correlation seems to be negative. The dashed blue line shows sea level variability as reproduced at the coastal stations by our 3-D model (without the inverted barometer effect) and the dotted blue line shows mean sea level variability associated with the inverted barometer effect only. In particular, the 3-D model reproduces observed sea level very well but underestimates the range of variability. The same can be said about the inverted barometer effect and both model results (3-D model plus inverted barometer effect) oscillate in phase with the observed sea level curve, but overestimate sea level rise during the last 10 years. On the other hand, the observational data subsequent to 1989 is of inadequate quality and therefore cannot be employed for robust evaluation of model performance.

\section{Conclusions}

[61] Summarizing the major results of this study we conclude the following.

[62] 1. Relative sea level monthly data from the 71 tide gauges in the Barents, Kara, Laptev, East Siberian, and Chukchi Seas have been analyzed in order to estimate the rate of sea level change and major factors responsible for this process in the Arctic Ocean.

[63] 2. The Arctic Ocean sea level time series have well pronounced decadal variability which corresponds to the variability of the North Atlantic Oscillation index. Because of the strength of this variability and the relatively short sea level time series, our assessments of sea level trends remain somewhat uncertain. In spite of this limitation, we have employed statistical methods together with numerical models and estimated the contributions of various factors to the observed sea level change. By subtracting the influence of these factors from the observed regional rate of sea level rise we have been able to estimate the rate of sea level rise due to increase of the global ocean mass that is presumably due to the melting of land ice.

[64] 3. During the period 1954-1989 the average rate of relative sea level rise over the seas of the Russian Arctic has been $0.185 \mathrm{~cm} \mathrm{yr}^{-1}$. This is within range of the rate that has previously been inferred using tide gauge data for the global ocean as a whole [IPCC, 2001]. It is also essentially the same as the rate for the Global Ocean recently inferred by Peltier [2002].

[65] 4. In the Arctic, the contribution to the observed rate of sea level rise from the steric effect is $0.064 \mathrm{~cm} \mathrm{yr}^{-1}$. This is smaller than the rate of ocean thermal expansion estimated for the global ocean by IPCC [2001]. In the Arctic Ocean, changes in salinity are more important for sea level variability than changes in temperature, and the combination of freshening of the Arctic seas with warming and salinization of the Atlantic layer therefore leads to the rise of sea level along coastlines and the fall of sea level in the central parts of the Arctic Basin.

[66] 5. The contribution of the inverse barometer effect to the Arctic Ocean sea level rise is $0.056 \mathrm{~cm} \mathrm{yr}^{-1}$. This is the highest rate of sea level rise among any of the estimates of this factor presented by IPCC [2001] for various regions. 
[67] 6. The estimated rate of sea level rise due to the effect of wind is $0.018 \mathrm{~cm} \mathrm{yr}^{-1}$, but it varies significantly from region to region. In the Arctic, this effect is due to the gradual decrease of the sea level atmospheric pressure over the Arctic Ocean and therefore to the more strongly cyclonic atmospheric circulation.

[68] 7. The contributions of river runoff, evaporation and precipitation to sea level change in the Arctic Ocean are very small and their cumulative effect is negligible. On the other hand, the P-E estimates over the Arctic Ocean are less accurate than the other investigated factors.

[69] 8. The residual term of the sea level rise balance assessment, $0.048 \mathrm{~cm} \mathrm{yr}^{-1}$, may be due to the increasing of the Arctic Ocean and global ocean mass associated with melting of ice caps and small glaciers and with adjustments of the Greenland and Antarctica ice sheets to the observed climate change.

[70] Acknowledgments. We are particularly grateful for guidelines and advice provided by Prof Philip Woodworth, Director of the Permanent Service for Mean Sea Level, United Kingdom for the preparation of the Arctic data for inclusion in the Permanent Service for Mean Sea Level database. His advice on the original project proposal and data analyses have also been very important. We also thank Dr. Sergei Priamikov for organization and management of this project at the Arctic and Antarctic Research Institute, St. Petersburg, Russia. Reanalysis data were provided by the NOAA-CIRES Climate Diagnostics Center, Boulder, Colorado, USA, from their Web site at http://www.cdc.noaa.gov/. This material is based upon work supported by the National Science Foundation under grant 0136432. It is contribution 10976 of the Woods Hole Oceanographic Institution.

\section{References}

Arctic Research Consortium of the United States (ARCUS) (1997), People and the Arctic: A prospectus for research on the human dimensions of the Arctic system, 75 pp., Fairbanks, Alaska.

Ashik, I. M., A. Y. Proshutinsky, and V. A. Stepanov (1989), Some results and prospects of numerical forecasts of storm surges in Arctic seas, Sov Meteorol. Hydrol., 8, 60-67.

Baker, T. F. (1993), Absolute sea level measurements, climate change and vertical crustal movements, Global Planet. Change, 8, 145-149.

Bannov-Baikov, Y. L. (1974), Statistical structure of large-scale sea level variability at the high latitudes of the Northern Hemisphere, Probl. Arct. Antarct., 45, 21-26.

Brown, J., and S. Solomon (2000), Arctic coastal dynamics: Report of an international workshop, Geol. Surv. Can. Open File Rep. 3929, 82 pp., Nat. Resources of Can., Ottawa. (Available at http://www.awi-potsdam. de/www-pot/geo/acd.html.)

Carmack, E. C., K. Aargaard, J. H. Swift, R. W. MacDonald, F. A. McLaughlin, E. P. Jones, R. G. Perkin, J. N. Smith, K. M. Ellis, and L. R. Killius (1997), Changes in temperature and tracer distributions within the Arctic Ocean: Results from the 1994 Arctic Ocean section, Deep Sea Res., Part II, 44, 1487-1502.

da Silva, A. M., C. C. Young, and S. Levitus (1994), Atlas of Surface Marine Data 1994, vol. 1, Algorithms and Procedures, NOAA Atlas NESDIS, vol. 6, 83 pp., Natl. Oceanic and Atmos. Admin., Silver Spring, Md.

Douglas, B. C. (1991), Global sea level rise, J. Geophys. Res., 96, 69816992.

Douglas, B. C. (1992), Global sea level acceleration, J. Geophys. Res., 97, $12,699-12,706$

Douglas, B. C. (1997), Global sea rise: A redetermination, Surv. Geophys., $18,279-292$.

Douglas, B. C. (2001), Sea level change in the era of the recording tide gauge, in Sea Level Rise: History and Consequences, Int. Geophys. Ser. vol. 75, edited by B. C. Douglas, M. S. Kearney, and S. P. Leatherman, pp. 37-62, Academic, San Diego, Calif.

Dvorkin, E. N. (1991), Possible changes in the sea level of the Arctic seas (in Russian), in Arctic Climate Regime at the 20th and 21st Centuries Transition, pp. 150-155, Gidrometeoizdat, St. Petersburg.

Dvorkin, E. N., Y. V. Zakharov, and N. V. Mustafin (1978), On the causes of seasonal and multiyear variability of sea level in the Laptev and east Siberian Seas (in Russian), Tr. AARI, 349, 60-68.

Dvorkin, E. N., Y. V. Zaharov, and N. V. Mustafin (1983), Seasonal and long-term variability of sea level in the Arctic seas, Probl. Arct. Antarct., $60,10-16$.
Dvorkin, E. N., S. Y. Kachanov, and N. P. Smirnov (2000), North Atlantic Oscillation and long-term variability of sea level in the Arctic seas, Sov. Meteorol. Hydrol., 3, 78-84.

Environmental Working Group (EWG) (1997), Joint U. S.-Russian Atlas of the Arctic Ocean [CD-ROM], Natl. Snow and Ice Data Cent., Boulder, Colo.

Environmental Working Group (EWG) (1998), Joint U. S.-Russian Atlas of the Arctic Ocean [CD-ROM], Natl. Snow and Ice Data Cent., Boulder, Colo.

Forman, S. L., and G. L. Johnson (1998), Prospectus for the RussianAmerican Initiative on Shelf-Land Environments in the Arctic (RAISE), 50 pp., Arct. Res. Consortium of the U. S., Fairbanks, Alaska.

Gornitz, V., and A. Solow (1991), Observations of long-term tide-gauge records for indicators of accelerated sea level rise, in Greenhouse GasInduced Climatic Change: A Critical Appraisal of Simulations and Observations, edited by M. E. Schlesinger, pp. 347-367, Elsevier Sci., New York.

Häkkinen, S., and G. L. Mellor (1992), Modeling the seasonal variability of the coupled Arctic ice-ocean system, J. Geophys. Res., 97, 20,28520,304 .

Intergovernmental Panel on Climate Change (IPCC) (2001), Climate Change 2001: The Scientific Basis-Contribution of Working Group I to the Third Assessment Report of IPCC, 994 pp., Cambridge Univ. Press, New York.

International Arctic Science Committee (IASC) (2000), Land-Ocean Interactions in the Russian Arctic: Implementation Plan, Moscow/Oslo-2000, 43 pp., Land-Ocean Interaction in the Russ. Arct., Oslo, Norway.

Mangerud, J., V. Astakhov, and J.-I. Swendsen (2002), The extent of the Barents-Kara ice sheet during the Last Glacial Maximum, Quat. Sci. Rev., 21, 111-119.

Pavlov, V. K. (2000), Seasonal and long-term variability of sea level in the marginal seas of the Arctic Ocean, in Geophysical Research Abstracts [CD-ROM], vol. 2, Eur. Geophys. Soc., Strasbourg, France.

Pavlov, V. K., and P. V. Pavlov (1999), Features of seasonal and interannual variability of sea level and water circulation in the Laptev Sea, in LandOcean Systems in the Siberian Arctic: Dynamics and History, edited by H. Kassens et al., pp. 3-16, Springer-Verlag, New York.

Peltier, W. R. (1986), Deglaciation induced vertical motion of the North American continent and transient lower mantle rheology, J. Geophys. Res., 91, 9099-9123.

Peltier, W. R. (1994), Ice age paleotopography, Science, 265, 195-201.

Peltier, W. R. (1996), Mantle viscosity and ice-age ice-sheet topography, Science, 273, 1359-1364.

Peltier, W. R. (1998), Postglacial variations in the level of the sea: Implications for climate dynamics and solid Earth geophysics, Rev. Geophys., 36, 603-689.

Peltier, W. R. (1999), Global sea level rise and glacial isostatic adjustment, Global Planet. Change, 20, 93-123.

Peltier, W. R. (2002), Global glacial isostatic adjustment: Paleogeodetic and space-geodetic tests of the ICE-4G (VM2) model, J. Quat. Sci., 17, 491510.

Peltier, W. R. (2004), Global glacial isostasy and the surface of the ice-age Earth: The ICE-5G (VM2) model and GRACE, Annu. Rev. Earth Planet. Sci., 32, 111-149.

Peltier, W. R., and A. M. Tushingham (1989), Global sea level rise and the greenhouse effect, might they be connected?, Science, 244, 806-810.

Peltier, W. R., and A. M. Tushingham (1991), Influence of glacial isostatic adjustment on tide gauge measurements of secular sea level change, J. Geophys. Res., 96, 6779-6796.

Peterson, B. J., R. M. Holmes, J. W. Mclelland, C. J. Vorosmarty, R. B. Lammers, A. I. Shiklomanov, I. A. Shiklomanov, and S. Rahmstort (2002), Increasing river discharge to the Arctic Ocean, Science, 298, $2171-2173$.

Proshutinsky, A. Y. (1978), On the computation of storm surges in the shelf zone of the Arctic Seas, Sov Meteorol. Hydrol, 8, 54-60.

Proshutinsky, A. Y. (1993), Arctic Ocean Sea Level Variability, 216 pp., Gidrometeoizdat, St. Petersburg.

Proshutinsky, A. Y., and M. Johnson (1997), Two circulation regimes of the wind-driven Arctic Ocean, J.Geophys. Res., 102, 12,493-12,514.

Proshutinsky, A., T. Proshutinsky, and M. Johnson (2000), Arctic climate oscillations from observations and model results, in Geophysical Research Abstracts [CD-ROM], vol. 2, Eur. Geophys. Soc., Strasbourg, France.

Proshutinsky, A., V. Pavlov, and R. Bourke (2001), Sea level rise in the Arctic Ocean, Geophys. Res. Lett., 28(11), 2237-2240.

Pugh, D. T. (1987), Tides, Surges, and Mean Sea Level, John Wiley, Hoboken, N. J.

Pugh, D. T., and G. A. Maul (1999), Coastal sea level prediction for climate change, in Coastal Ocean Prediction, Coastal Estuarine Ser., vol. 56, pp. 377-404, edited by C. N. K. Mooers, AGU, Washington, D. C. 
Quadfasel, D., A. Sy, and D. Wells (1991), Warming in the Arctic, Nature, 350,385

Shaw, J., R. B. Taylor, S. Solomon, H. A. Christian, and D. L. Forbes (1998), Potential impacts of global sea level rise on Canadian coasts, Can. Geogr., 42, 365-379.

Smith, O. P., and L. Johnson (2000), The warming world: Effects on the Alaska infrastructure, in Synthesis of Workshop Proceedings, January 56, 2000, Anchorage, Alaska, pp. 2-5, Univ. of Alaska, Anchorage.

Swift, J. H., E. P. Jones, K. Aagaard, E. C. Carmack, M. Hingston, R. W. MacDonald, F. A. McLaughlin, and R. G. Perkin (1997), Waters of the Makarov and Canada Basins, Deep Sea Res., Part II, 44, 1503-1529.

Tarasov, L., and W. R. Peltier (2002), Greenland glacial history and local geodynamic consequences, Geophys. J. Int., 150, 198-229.

Tushingham, A. M., and W. R. Peltier (1991), ICE-3G: A new global model of late Pleistocene deglaciation based upon geophysical predictions of post-glacial relative sea level change, J. Geophys. Res., 96, 4497-4523.

Vorobyov, V. N., S. Y. Kochanov, and N. P. Smirnov (2000), Seasonal and Multiyear Sea-Level Fluctuations in the Arctic Ocean, 113 pp., Minist. of Educ. of Russ. Fed., St. Petersburg.
Walsh, J. E., W. L. Chapman, and T. L. Shy (1996), Recent decrease of sea level pressure in the central Arctic, J. Clim., 9, 480-486.

Woodworth, P. L. (1993), A review of recent sea level research, Oceanogr. Mar. Biol. Annu. Rev., 31, 87-109.

Woodworth, P. L., D. T. Pugh, J. G. De Ronde, R. G. Warrick, and J. Hannah (Eds.) (1992), Sea Level Changes: Determination and Effects, Geophys. Monogr. Ser., vol. 69, 208 pp., AGU, Washington, D. C.

I. M. Ashik and E. N. Dvorkin, Arctic and Antarctic Research Institute, 38 Bering Str., St. Petersburg, Russia 199397.

S. Häkkinen, Goddard Space Flight Center, Code 971, B33, RmA221, Greenbelt, MD 20771, USA.

R. A. Krishfield and A. Proshutinsky, Department of Physical Oceanography, Woods Hole Oceanographic Institution, MS\# 29, 360 Woods Hole Road, Woods Hole, MA 02543, USA. (aproshutinsky@whoi.edu)

W. R. Peltier, Department of Physics, University of Toronto, 60 St. George Street, Toronto, Ontario, Canada, M5S 1A7. 